\title{
Results of the implementation of the System for the Integrated Assessment of Protected Areas (SIAPA) to the protected areas of the Autonomous Region of Madrid (Spain)
}

\author{
David Rodríguez-Rodríguez, Javier Martínez-Vega \\ Keywords: Effectiveness assessment - Protected area - Autonomous Region of Madrid - SIAPA.
}

\begin{abstract}
The long-term conservation of biodiversity and related ecosystems goods and services of the Autonomous Region of Madrid is jeopardized by the intensive resource-consuming development model followed by the region in the past few decades. This paper presents the aggregated results of the first integrated assessment of the protected areas of the Autonomous Region of Madrid (Spain) with the System for the Integrated Assessment of Protected Areas (SIAPA). Detailed results are also provided for individual protected areas as supplementary data. The assessment was done during 2009-2010, on ten protected areas differing in their sizes (from 2.5 to 52,796 ha), protection categories (seven categories) and types of ecosystems present. Comparison of results from both assessment models of the SIAPA (the Complete Model and the Simplified Model) is also presented. The results from the Complete Model show that eight out of the ten protected areas of the Autonomous Region of Madrid are currently ineffective. The poorest partial indexes overall were: "State of Conservation" and "Social and Economic Context". The only indexes significantly correlated with the effectiveness of a protected area were: the "State of Conservation" $\left(\mathrm{r}=0.851^{* *}\right)$ and the "Social Perception and Valuation" $\left(\mathrm{r}=0.786^{* *}\right)$. Although not as relevant as was thought, "Management" and the other non-significant factors are likely to influence the effectiveness of protected areas as well. The results for the Simplified Model are slightly better than those for the Complete Model, although this is probably a specific result of this assessment. The two models of the SIAPA were very significantly correlated, although their aggregated results should not be compared directly.
\end{abstract}

\section{Introduction}

\subsection{Need for an effectiveness assessment of the protected areas of the Autonomous Region of Madrid}

The Autonomous Region of Madrid is a Spanish region of $8021 \mathrm{~km} 2$ located in the centre of Spain (Fig. 1). It includes the capital of Spain and the capital of the Region: the city of Madrid, together with its large metropolitan area. In 2011, there were 6,489,680 inhabitants living in the region which accounts for 809 inhabitants $/ \mathrm{km} 2$, the highest population density in Spain (INE, 2012). The region has a rich natural and cultural patrimony which is jeopardized by the implementation of an intensive resource-consuming development model (Naredo and Frías, 2005; VVAA, 2005; Mata et al., 2009) that has led to an increase in economic standards but also to the development of large industrial areas, residential areas and infrastructures throughout the region from the 1950s (Chicharro, 1976; Díaz-Muñoz, 1984; Gutiérrez, 1998; Naredo, 2008; Naredo and García-Zaldívar, 2008) and, especially, in the past 20 years (Gago et al., 2004; Delgado, 2008; Fernández-Muñoz, 2008; Gallardo and Martínez-Vega, 2010, 2012). Similar pressures have been stated for other regions with akin characteristics, in
Europe (Jongman, 2002) and elsewhere (Radeloff et al., 2010).

The protected areas (PAs) of the region of Madrid face numerous pressures, mainly from massive visitor use and intensive land-use transformation (Rodríguez-Rodríguez, 2008; Hewitt and Escobar, 2011; Pérez-Hugalde et al., 2011), in addition to more general threats arising from global change, such as climate change (Araújo et al., 2011). These dynamics raise concern that effective longterm conservation of biodiversity and related goods and services provided by the region's ecosystems cannot be achieved despite the fact that up to $46 \%$ of its territory is under some kind of protection regime (Mata et al., 2009). Thus, the assessment of the effectiveness of the 10 PAs of the Autonomous Region of Madrid is crucial not only to help safeguard biodiversity and the related ecosystem services provided by the most important natural places in the region, but also to give an indication on whether sustainable development could be attained in practice using this miniature world replica which is the region of Madrid as an example. Such assessment comes from a legal mandate to monitor, assess and report on the state and trends of biodiversity by the CBD (CBD, 1992) and the Spanish national law on nature conservation1. Moreover, it is endorsed by national and international strategic documents on PAs like the "Action Plan for the Protected Areas of Spain” (Europarc-España, 2002), the 


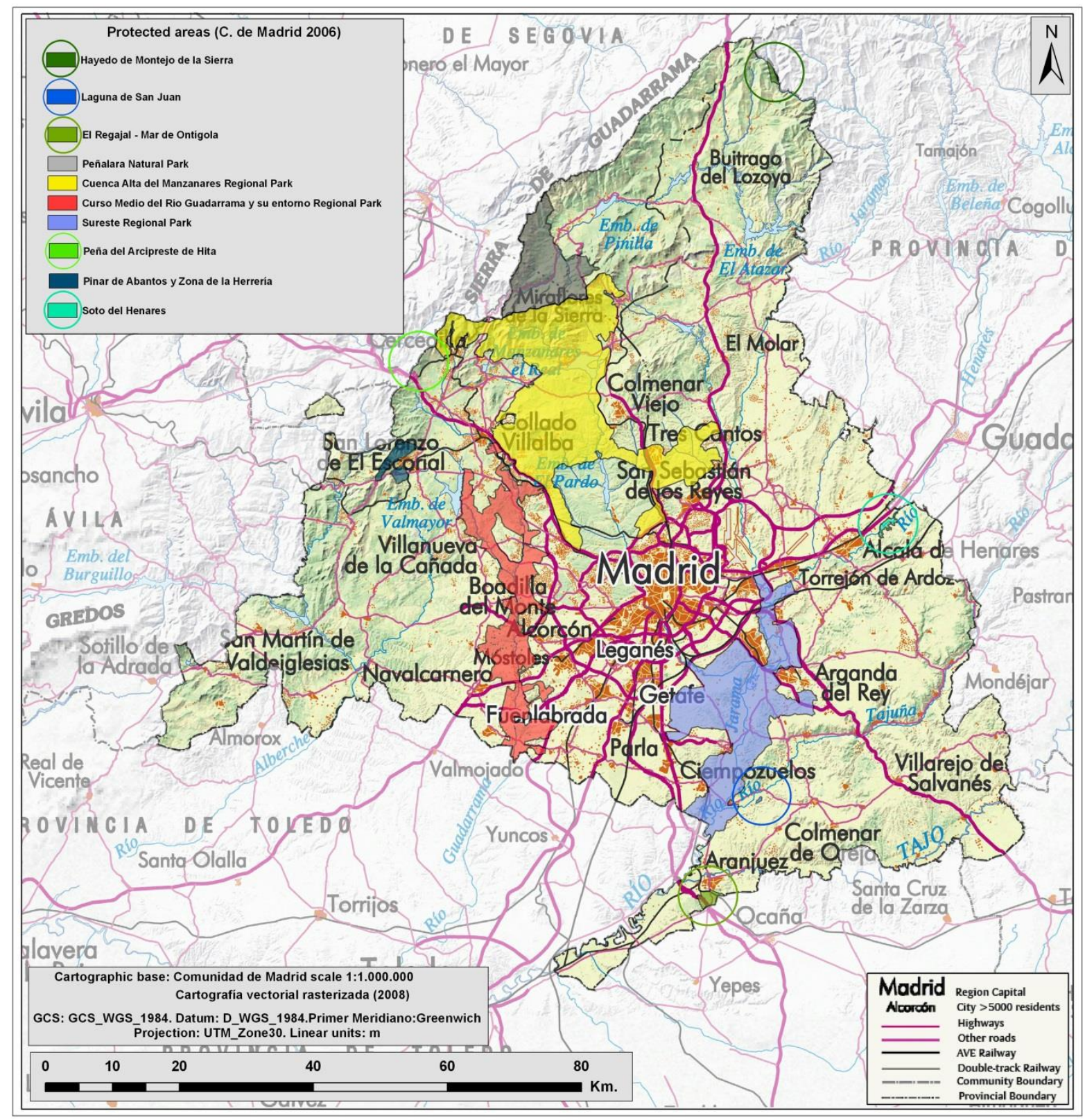

Fig. 1. Location of the protected areas of the Autonomous Region of Madrid.

"Work Programme for protected areas 2009-2013" (Europarc-Spain, 2009), or the "Programme of Work on Protected Areas of the CBD" (CBD, 2004).

The results presented in this paper will help PA managers, PA network managers and decision makers in the region of Madrid to make better management decisions based on the best available information for improved conservation. They will also provide a reference for PA managers and PA network managers in other regions of Spain, Europe and elsewhere, especially for metropolitan regions in the Euro-Mediterranean context. Finally, the results shown here will also help Spain fulfil its current PA monitoring, assessment and reporting commitments under the Convention of Biological Diversity (CBD, 2010).

\subsection{Aims of the study}

The ultimate aim of this study was to enhance the capacity of the 10 PAs of the Autonomous Region of Madrid to conserve biodiversity and provide ecosystem 
goods and services in the long term through improved information and management.

The specific aims were to: (1) assess the effectiveness of the ten PAs of the region of Madrid in an integrated and comparative manner using the System for the Integrated Assessment of Protected Areas (SIAPA; RodríguezRodríguez and Martínez-Vega, 2012); (2) assist managers and decision-makers in the region to make informed management decisions; (3) make comprehensive and updated information on the PAs of the region of Madrid avail-able to any interested body or individual; (4) summarize the main results and the lessons learned from the development and pilot implementation of the SIAPA

\section{Methods}

\subsection{Selection of the protected areas to be assessed}

The 10 PAs designated by the Government of the Autonomous Region of Madrid were selected on the grounds of the coherence of the study, the limited time and resources available to conduct it, and the availability of basic information (Table 1). These PAs make up the basic conservation network of the Region. The Regional Ministry of Environment (CMAOT, Consejería de Medio Ambiente y Ordenación del Territorio) is competent for their management. Other PAs in the Region of Madrid designated under European laws or international agreements such as Natura 2000 sites (Natura 2000 Protected Areas2) or Biosphere Reserves (Areas Protected by International Instruments3) outside those PAs were excluded from the assessment because most of the basic information for an assessment was missing.

Together, the 10 PAs selected for the assessment account for roughly 120,898 ha, or approximately $15 \%$ of the area of the Autonomous Region of Madrid (Fig. 1).

\subsection{Data collection}

Data were collected during 2009 and the beginning of 2010 by different methods (Table 2 ). The data collection and the assessment were done by the Institute of Economics, Geography and Demography of the Spanish National Research Council (IEGD-CSIC), a national scientific body external to the managing body and the regional administration. Even if basic information to measure an indicator was not available (this happened for three indicators), we maintained these indicators in the SIAPA to identify knowledge gaps and to encourage future acquisition of that information, as suggested by Ramírez (2002) and Fraser et al. (2006).

Table 1

Protected areas considered in this assessment

\begin{tabular}{|c|c|c|c|c|}
\hline Protected area & Abbreviation & $\begin{array}{l}\text { Area } \\
\text { (ha) }\end{array}$ & $\begin{array}{l}\text { Designation } \\
\text { year }\end{array}$ & Conservation target(s) \\
\hline Peñalara Natural Park & Peñalara NP & 11,637 & 1990 & Geomorphology \\
\hline $\begin{array}{l}\text { Cuenca Alta del Manzanares } \\
\text { Regional Park }\end{array}$ & Cuenca Alta RP & 52,796 & 1985 & $\begin{array}{l}\text { Multiple: environmental; cultural; } \\
\text { agricultural; landscape; ecological corridor }\end{array}$ \\
\hline Sureste Regional Park & Sureste RP & 31,550 & 1994 & $\begin{array}{l}\text { Multiple: ecological; palaeontological; } \\
\text { archaeological }\end{array}$ \\
\hline $\begin{array}{l}\text { Curso Medium del Río } \\
\text { Guadarrama y su entorno Regional } \\
\text { Park }\end{array}$ & Guadarrama RP & 22,116 & 1999 & $\begin{array}{l}\text { Multiple: natural; cultural; water } \\
\text { ecosystems; landscape; ecological corridor; } \\
\text { tourism }\end{array}$ \\
\hline $\begin{array}{l}\text { Pinar de Abantos y Zona de la } \\
\text { Herrería Picturesque Landscape }\end{array}$ & $\begin{array}{l}\text { Pinar Abantos y } \\
\text { Herrería PL }\end{array}$ & 1,538 & 1961 & Landscape \\
\hline $\begin{array}{l}\text { Natural Site of National Interest of } \\
\text { Hayedo de Montejo de la Sierra }\end{array}$ & $\begin{array}{l}\text { NSNI Hayedo } \\
\text { Montejo }\end{array}$ & 250 & 1974 & $\begin{array}{l}\text { Multiple; relict ecosystem; landscape; } \\
\text { scientific; education }\end{array}$ \\
\hline $\begin{array}{l}\text { El Regajal-Mar de Ontígola } \\
\text { Natural Reserve }\end{array}$ & $\begin{array}{l}\text { Regajal-Ontígola } \\
\text { NR }\end{array}$ & 629 & 1994 & $\begin{array}{l}\text { Multiple: fauna (lepidoptera; birds), } \\
\text { botanical }\end{array}$ \\
\hline Laguna de San Juan Fauna Refuge & $\begin{array}{l}\text { Laguna San Juan } \\
\text { FR }\end{array}$ & 47 & 1991 & $\begin{array}{l}\text { Multiple: fauna; geomorphology; } \\
\text { landscape; scientific; education }\end{array}$ \\
\hline $\begin{array}{l}\text { Natural Monument of National } \\
\text { Interest of Peña del Arcipreste de } \\
\text { Hita }\end{array}$ & $\begin{array}{l}\text { NMNI Peña } \\
\text { Arcipreste }\end{array}$ & 2.5 & 1930 & Cultural \\
\hline $\begin{array}{l}\text { Preventive Protection Regime of } \\
\text { Soto del Henares }\end{array}$ & PPR Soto Henares & 332 & 2000 & $\begin{array}{l}\text { Mutiple: riparian ecosystem; landscape; } \\
\text { ecological corridor }\end{array}$ \\
\hline
\end{tabular}




\subsection{Data integration}

Once the information for each of the 43 indicators was compiled from different sources (Table 2), they were integrated into the six partial assessment indexes (State of conservation, Planning, Management, Social and economic context, Social perception and valuation, and Threats to conservation) according to the average weights given to them by the experts consulted.

These partial indexes were later weighted by the same experts in a second round of consultations and subsequently integrated into the Effectiveness Index, according to the integration procedure shown in Rodríguez-Rodríguez and Martínez-Vega (2012).

\subsection{Assessment}

The complete assessment was carried out during 2010, according to the methodology described by RodríguezRodríguez and Martínez-Vega (2012)

Table 2

Data sources and methods of collection of information on the indicators of the SIAPA

\begin{tabular}{|c|c|c|}
\hline Source & Method & Indicator \\
\hline Local population & Telephone survey & $\begin{array}{l}\text { Degree of knowledge on the protected area; State of conservation; Personal } \\
\text { importance; Economic valuation; Activities performed by visitors }(p) .\end{array}$ \\
\hline $\begin{array}{l}\text { Division of Protected Areas of the } \\
\text { Regional Ministry of Environment }\end{array}$ & $\begin{array}{l}\text { Personal interviews with } \\
\text { managers }\end{array}$ & $\begin{array}{l}\text { Existence of updated documents on social and economic development }(p) \text {; } \\
\text { Existence of updated documents on public use; Degree of fulfillment of } \\
\text { management objectives; Existence of sufficient management staff }(p) ; \text { Evolution } \\
\text { of investment in the protected area (p); Effectiveness of public participation } \\
\text { bodies }(p) ; \text { Production and distribution of an annual report on activities and } \\
\text { outcomes }(p) ; \text { Existence of environmental education and volunteering activities; } \\
\text { Monitoring activities; Land ownership; Presence of alien invasive species }(p) \text {; } \\
\text { Activities performed by visitors }(p) \text {. }\end{array}$ \\
\hline $\begin{array}{l}\text { Environmental Information Division of } \\
\text { the Regional Ministry of Environment }\end{array}$ & $\begin{array}{l}\text { Information requested by } \\
\text { e-mail }\end{array}$ & $\begin{array}{l}\text { Zoning }(p) ; \text { Evolution of the area designated as protected }(p) ; \text { Production and } \\
\text { distribution of an annual report on activities and outcomes }(p) \text {. }\end{array}$ \\
\hline $\begin{array}{l}\text { Website of the Regional Ministry of } \\
\text { Environment }\end{array}$ & $\begin{array}{l}\text { Direct consultation or data } \\
\text { download }\end{array}$ & $\begin{array}{l}\text { Air quality; Appropriateness of protection legislation; Existence of updated } \\
\text { planning documents; Existence of updated management documents, Production } \\
\text { and distribution of an annual report on activities and outcomes }(p) \text {. }\end{array}$ \\
\hline $\begin{array}{l}\text { Sciences library of the Autonomous } \\
\text { University of Madrid; Protected Areas } \\
\text { Information Centre; Library of the } \\
\text { Faculty of Biology of the Complutense } \\
\text { University of Madrid; Library of the } \\
\text { Regional Ministry of Environment; } \\
\text { Spanish National Research Council } \\
\text { Library Network; Scientific online } \\
\text { databases (Web of Knowledge, online } \\
\text { servers) }\end{array}$ & Bibliographic review & $\begin{array}{l}\text { Surface water quality }(p) ; \text { Zoning }(p) ; \text { Evolution of the area designated as } \\
\text { protected }(p) ; \text { Degree of characterization of the protected area; Production and } \\
\text { distribution of an annual report on activities and outcomes }(p) ; \text { Number of } \\
\text { municipalities in the protected area; Presence of alien invasive species }(p) ; \\
\text { Activities performed by visitors }(p) \text {. }\end{array}$ \\
\hline $\begin{array}{l}\text { Forest Rangers Corps of the Regional } \\
\text { Ministry of Environment }\end{array}$ & Telephone interview & $\begin{array}{l}\text { Existence of sufficient management staff ( } p) \text {; Presence of alien invasive species } \\
(p) ; \text { Activities performed by visitors }(p) \text {. }\end{array}$ \\
\hline $\begin{array}{l}\text { Centre for Environmental Research of } \\
\text { the Autonomous Region of Madrid }\end{array}$ & $\begin{array}{l}\text { Information requested by } \\
\text { e-mail }\end{array}$ & $\begin{array}{l}\text { Surface water quality }(p) ; \text { Evolution of investment in the protected area }(p) \text {; } \\
\text { Production and distribution of an annual report on activities and outcomes }(p) \text {; } \\
\text { Number of visitors. }\end{array}$ \\
\hline $\begin{array}{l}\text { Internal information from divisions of } \\
\text { the Regional Ministry of Environment: } \\
\text { Flora and Fauna, Pests, Environmental } \\
\text { Discipline, Cartographic Information }\end{array}$ & $\begin{array}{l}\text { Information requested by } \\
\text { post; data supplied by e- } \\
\text { mail or other electronic } \\
\text { media }\end{array}$ & $\begin{array}{l}\text { Evolution of populations of endangered species or subspecies; Health of } \\
\text { vegetation; Landscape impact; Sanctioning procedures; Fragmentation }(p) ; \\
\text { Isolation ( } p) \text {; Accessibility. }\end{array}$ \\
\hline Visits to protected areas & Census; visual inspection & $\begin{array}{l}\text { Presence of solid waste ( } p) \text {; Easiness to identify the protected area; Public use } \\
\text { infrastructure; Presence of alien invasive species }(p) ; \text { Activities performed by } \\
\text { visitors }(p) \text {. }\end{array}$ \\
\hline $\begin{array}{l}\text { Website of the National Geographical } \\
\text { Institute (Corine Land-Cover) }\end{array}$ & Data download & Presence of solid waste (p); Land use changes; Fragmentation (p); Isolation ( $p)$. \\
\hline $\begin{array}{l}\text { Website of the Regional Foundation for } \\
\text { Environmental Research and } \\
\text { Development }\end{array}$ & Direct consultation & Area provided for the protected area by municipalities under local Agenda 21 \\
\hline $\begin{array}{l}\text { Institute of Economics, Geography and } \\
\text { Demography }\end{array}$ & GIS analysis & Landscape impact; Area affected by fires \\
\hline $\begin{array}{l}\text { Website of the Regional Institute of } \\
\text { Statistics }\end{array}$ & Direct consultation & Local population density \\
\hline National Meteorological Agency & $\begin{array}{l}\text { Requested by post; data } \\
\text { provided by e-mail }\end{array}$ & Climate change \\
\hline $\begin{array}{l}\text { Website of the Tajo River Basin } \\
\text { Management Agency (ICA network) }\end{array}$ & Data download & Surface water quality $(p)$ \\
\hline \multicolumn{2}{|l|}{ No data or indicator not developed $*$} & $\begin{array}{l}\text { Evolution of feature(s) for which the protected area was designated; Sanctioning } \\
\text { procedures; Main economic activities in the protected area* }\end{array}$ \\
\hline
\end{tabular}

(p): partially compiled 
Pearson's tests were performed to determine the degree of relatedness among the indexes and to compare the results obtained with the two models of the SIAPA: the Complete Model (CM) and the Simplified Model (SM).

\subsection{Result communication and interpretation}

The results of the implementation of the SIAPA are presented at different levels in order to extract the maximum possible information from the assessment and to simplify the communication of results (Paleczny and Russell, 2005): (1) by PA (using the Complete Model; supplementary data); (2) by index (using the Complete Model): State of Conservation, Planning, Management, Social and Economic Context, Social Perception and Valuation, Threats to Conservation, and Effectiveness; and (3) by model.

In order to clearly convey the results of the SIAPA to any interested person regardless of his or her degree of knowledge on the topic, a code based on happy faces (adequate valuation), normal faces (moderate valuation) and sad faces (deficient valuation) was developed (Table $3)$.

\subsection{Statistical testing}

We used multiple regression analysis to assess the degree of relatedness between the indicators and the indexes used in the SIAPA. We also tested different statistical techniques for grouping and reducing the information portrayed by the indicators. Principal Component analysis and Correspondence analysis were performed on the results of the Complete Model of the SIAPA using SPSS software to this end

Table 3

Communication and representation coding used in the SIAPA

\begin{tabular}{|c|c|c|}
\hline & Interpretation & Valuation \\
\hline \multicolumn{3}{|c|}{ State } \\
\hline & Adequate & 2 points \\
\hline & Moderate & 1 point \\
\hline & Deficient & 0 points \\
\hline ¿? & \multirow{2}{*}{\multicolumn{2}{|c|}{$\begin{array}{l}\text { Data absent or unusable } \\
\text { Not applicable }\end{array}$}} \\
\hline NA & \\
\hline Tenc & & \\
\hline$\uparrow$ & \multicolumn{2}{|l|}{ Positive } \\
\hline$\leftrightarrow$ & \multicolumn{2}{|l|}{ Stable } \\
\hline$\downarrow$ & \multicolumn{2}{|l|}{ Negative } \\
\hline ¿? & \multicolumn{2}{|l|}{ Data are absent or non-usable } \\
\hline NA & \multicolumn{2}{|l|}{ Not applicable } \\
\hline
\end{tabular}

\section{Results}

Results are global and highly aggregated on space grounds. Individual results for each PA are provided as supplementary data.

The results of both models for the six partial indexes and for the Effectiveness Index (EI) are presented in Tables 4 and 5 .

Table 4

Results for the six partial indexes plus the Effectiveness Index from the application of the Complete Model of the SIAPA to the 10 PAs of the Region of Madrid according to the $(0 ; 1 ; 2)$ standardized scale (Rodríguez-Rodríguez and Martínez-Vega, 2012)

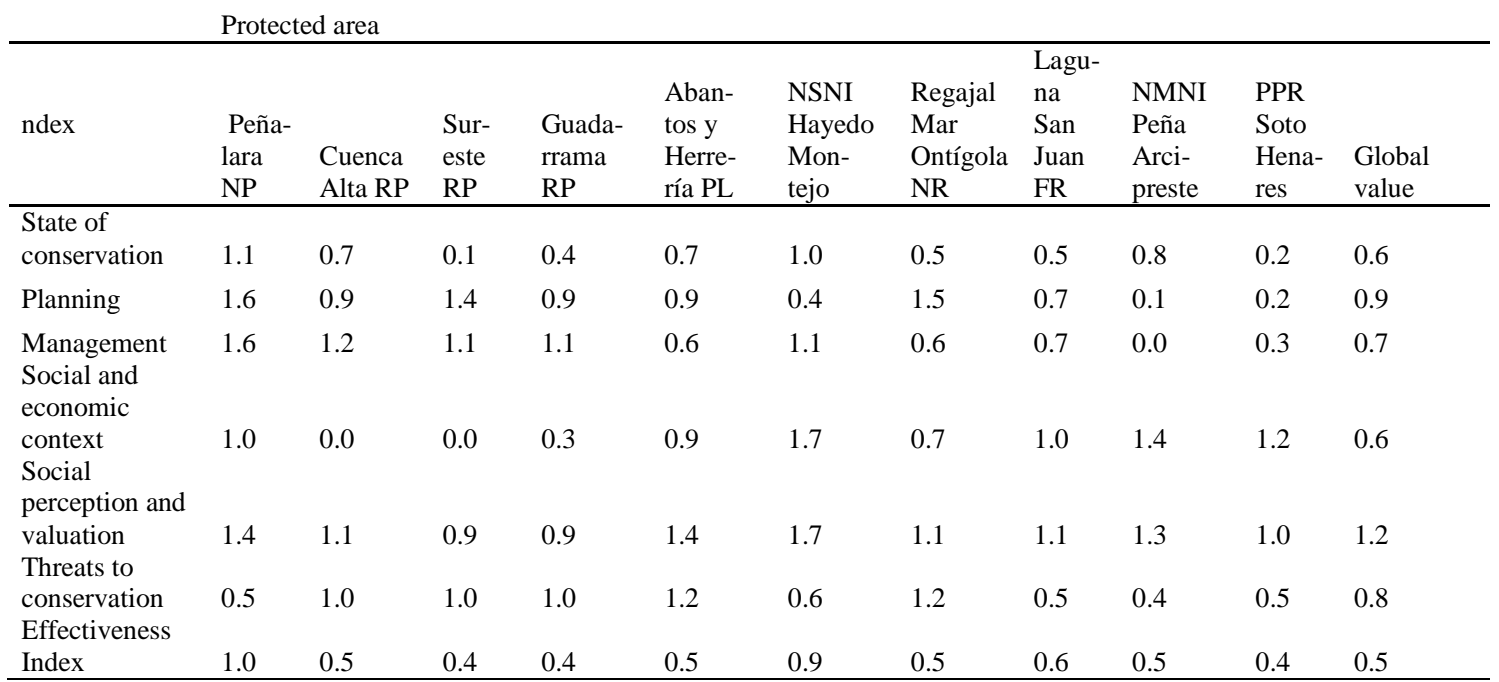

NP: Natural Park, RP: Regional Park, PL: Picturesque Landscape, NSNI: Natural Site of National Interest, FR: Fauna Refuge, NMNI Natural Monument of National Interest, PPR: Preventive Protection Regime. 
Table 5

Results for the six partial indexes plus the Effectiveness Index from the application of the Simplified Model of the SIAPA to the 10 PAs of the Region of Madrid according to the $(0 ; 1 ; 2)$ standardized scale (Rodríguez-Rodríguez and Martínez-Vega, 2012)

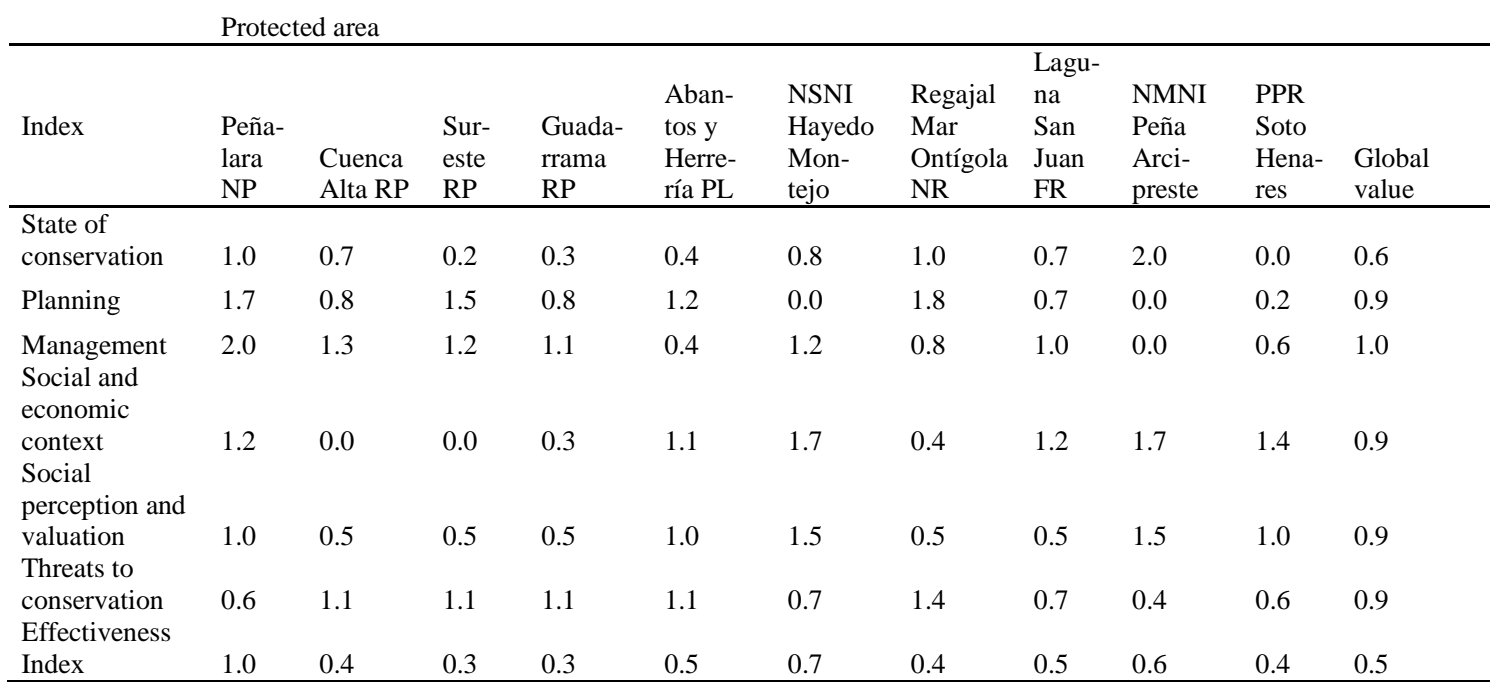

NP: Natural Park, RP: Regional Park, PL: Picturesque Landscape, NSNI: Natural Site of National Interest, FR: Fauna Refuge, NMNI Natural Monument of National Interest, PPR: Preventive Protection Regime.

The interpretation of the results shown in Table 4 is presented, by PA, in Table 6 .

Pearson's correlations among the indexes are shown in Table 7.

Both, the CM and the SM are highly and very significantly correlated $(\mathrm{r}=0.882 * *)$. Inter-pair index correlations between the two models are shown in Table 8 .

The percentage of indicators for which there were no data was slightly higher for the SM (15.4\%) than for the CM $(11.2 \%)$ because two of the three indicators which could not be valuated remained in the SM. The average number of PAs for which indicators could be valuated was similar: $9.0 / 10$ with the $\mathrm{SM}$ and $8.8 / 10$ with the $\mathrm{CM}$

\section{Discussion}

\subsection{Per index}

\subsubsection{State of conservation index (SCI)}

The state of conservation of the PAs of the Autonomous Region of Madrid can be deemed "Deficient" in general. A complete record of threatened species was not available for any PA, and the air quality, surface water quality and the number of landscape impacts scores were low in general. As a result, the state of conservation of all PAs except two: Peñalara NP (SCI = 1.1 ) and NSNI Hayedo Montejo (SCI $=1.0$ ) is "Deficient". The PA which scored the lowest was Sureste RP for which 5 of its 6 constituent indicators scored "Deficient", followed by PPR Soto Henares, and Guadarrama RP. These three PAs comprise over 53,000 ha, or approximately $44 \%$ of the total area covered by the 10 PAs of the Autonomous Region of Madrid. Thus, the existence of a protection status for many years (and active management, in the case of the parks) did not result in effective conservation of some PAs. Surprisingly, the SCI was not significantly correlated with the Planning Index (PLI), the Management Index (MAI), the Social and Economic Context Index (SEI) or the Threats to Conservation Index (TCI). It was highly and significantly correlated with the Social Perception and Valuation Index (SPI) and the EI, however. This suggests that the main factor influencing the conservation state of a PA in the region is the degree of social support (Leverington et al., 2010).

\subsubsection{Planning index (PLI)}

Planning of the 10 PAs of the Autonomous Region of Madrid is partially deficient. Only two PAs have adequate planning: Peñalara NP and Regajal-Ontígola NR. Sureste $\mathrm{RP}$ is better planned than the remainder, which are poorly planned. The other two regional parks have "Deficient" planning. Cuenca Alta RP has neither a natural resource plan nor a social and economic plan; it does not have a designated zone of social and economic influence and it is managed through an outdated management plan. Similarly, Guadarrama RP has no management plan, social and economic plan, or a designated zone of social and economic influence, and it is managed with an outdated natural resource plan. The lowest scores were for: NMNI Peña Arcipreste (PLI = 0.1), PPR Soto Henares $(\mathrm{PLI}=0.2)$, and NSNI Hayedo Montejo (PLI = 0.4). All three have inappropriate or outdated protection categories, have no natural resource plan or management plan, and no zoning. Therefore, better planning is needed, especially in these PAs, as a prerequisite for appropriate management. 
Table 6

Symbolic representation of the aggregated results of the implementation of the Complete Model of the SIAPA to the 10 protected areas of the Autonomous Region of Madrid

\begin{tabular}{|c|c|c|c|c|c|c|c|}
\hline \multirow{2}{*}{ Protected area } & \multicolumn{7}{|c|}{ Index } \\
\hline & $\begin{array}{c}\text { State of } \\
\text { Conservation }\end{array}$ & Planning & Management & $\begin{array}{c}\text { Social and } \\
\text { Economic } \\
\text { Context }\end{array}$ & $\begin{array}{c}\text { Social } \\
\text { Perception } \\
\text { and } \\
\text { Valutation }\end{array}$ & $\begin{array}{c}\text { Threats } \\
\text { to } \\
\text { conservation }\end{array}$ & Effectiveness \\
\hline Peñalara NP & & & & & & & \\
\hline Cuenca Alta RP & & & & & & & \\
\hline Sureste RP & & & & & & & \\
\hline Guadarrama RP & & & & & & & \\
\hline $\begin{array}{l}\text { Pinar Abantos y } \\
\text { Herrería PL }\end{array}$ & & & & & & & \\
\hline NSNI Hayedo & & & & & & & \\
\hline Montejo & & & & & & & \\
\hline $\begin{array}{l}\text { El Regajal- } \\
\text { Ontígola NR }\end{array}$ & & & & & & & \\
\hline Laguna San Juan & & & & & & & \\
\hline FR & & & & & & & \\
\hline NMNI Peña & & & & & & & \\
\hline Arcipreste & & & & & & & \\
\hline PPR Soto & & & & & & & \\
\hline Henares & & & & & & & \\
\hline $\begin{array}{l}\text { Total protected } \\
\text { areas }\end{array}$ & & & & & & & \\
\hline
\end{tabular}

NP: Natural Park, RP: Regional Park, PL: Picturesque Landscape, NSNI: Natural Site of National Interest, FR: Fauna Refuge, NMNI: Natural Monument of National Interest, PPR: Preventive Protection Regime.

Table 7

Pearson's correlations (r) among the indexes of the SIAPA

\begin{tabular}{llrrrrrrr}
\hline Index & & \multicolumn{1}{c}{ SCI } & \multicolumn{1}{c}{ PLI } & \multicolumn{1}{l}{ MAI } & \multicolumn{1}{l}{ SEI } & \multicolumn{1}{l}{ SPI } & \multicolumn{1}{l}{ TCI } & \multicolumn{1}{c}{ EI } \\
\hline \multirow{2}{*}{ SCI } & $\mathrm{r}$ & 1 & .028 & .324 & .460 & $.833^{* *}$ & -.329 & $.851^{* *}$ \\
& $p$ & & .935 & .331 & .155 & .001 & .323 & .001 \\
PLI & $\mathrm{r}$ & .028 & 1 & .592 & -.550 & -.193 & .600 & .153 \\
& $p$ & .935 & & .055 & .080 & .570 & .051 & .653 \\
MAI & $\mathrm{r}$ & .324 & .592 & 1 & -.359 & .085 & .167 & .504 \\
& $p$ & .331 & .055 & & .279 & .804 & .625 & .114 \\
SEI & $\mathrm{r}$ & .460 & -.550 & -.359 & 1 & $.731^{*}$ & $-.677^{*}$ & .558 \\
& $p$ & .155 & .080 & .279 & & .011 & .022 & .075 \\
SPI & $\mathrm{r}$ & $.833^{* *}$ & -.193 & .085 & $.731^{*}$ & 1 & -.330 & $.786^{* *}$ \\
& $p$ & .001 & .570 & .804 & .011 & & .321 & .004 \\
TCI & $\mathrm{r}$ & -.329 & .600 & .167 & $-.677^{*}$ & -.330 & & -.445 \\
& $p$ & .323 & .051 & .625 & .022 & .321 & & .171 \\
EI & $\mathrm{r}$ & $.851^{* *}$ & .153 & .504 & .558 & $.786^{* *}$ & -.445 & 1 \\
& $p$ & .001 & .653 & .114 & .075 & .004 & .171 &
\end{tabular}

SCI: State of Conservation Index. PLI: Planning Index. MAI: Management Index. SEI: Social and Economic Context Index. SPI: Social Perception and Valuation Index. TCI: Threats to Conservation Index. EI: Effectiveness Index.

${ }^{* *}$ Significant at $\alpha=0.01 ;{ }^{*}$ Significant at $\alpha=0.05 ; \mathrm{n}=11$. 
Table 8

Inter-pair index correlations between the Complete and the Simplified Model of the SIAPA.

\begin{tabular}{ll}
\hline Index & $\mathrm{r}$ \\
\hline State of Conservation & $0.898^{* *}$ \\
Planning & $0.973^{* *}$ \\
Management & $0.942^{* *}$ \\
Social and Economic Context & $0.957^{* *}$ \\
Social Perception and Valuation & $0.775^{* *}$ \\
Threats to Conservation & $0.985^{* *}$ \\
Effectiveness & $0.947 * *$ \\
\hline$* *$ Significant at $p<0.01$ &
\end{tabular}

**Significant at $p<0.01$

The PLI was not correlated with any of the other indexes, although its value was close to the significance level of 0.05 for the TCI and the MAI.

\subsubsection{Management index (MAI)}

Despite the stated importance of management for the effective conservation of PAs (Pomeroy et al., 2005; Hockings et al., 2006), this index did not reach a minimum desirable value in the PAs of the Autonomous Region of Madrid. Only Peñalara NP has "Adequate" management. Whereas four PAs, including the three regional parks and the NSNI Hayedo Montejo, has a "Moderate" management valuation, the other five PAs have all "Deficient" valuations. The lowest value was for NMNI Peña Arcipreste (MAI $=0)$, as all its indicators scored 0 or lacked any information to be valuated. The MAI of PPR Soto Henares was also extremely low (MAI $=0.3$ ). Low scores were found for two PAs which had a director at the moment of the assessment: Regajal-Ontígola NR (MAI = 0.6 ) and Laguna San Juan FR (MAI = 0.7). This might be due to the scarce attention paid by the administration to these two PAs, and because of the excessive amount of work of the director, who had to make compatible the management of both PAs with the management of one of the biggest and most conflicting PAs: the Sureste RP (Rodríguez-Rodríguez, 2008).

A set of direct causes could explain the poor quality of management, as mentioned by Nolte et al. (2010) and Pomeroy et al. (2005): competence and information dispersal among different administrative units, poor coordination among these units on policies and activities related to PAs, shortage of human and material resources devoted to management, insufficient updated scientific knowledge among managers, and weak institutional support to biodiversity conservation policies.

In contrast to what we had expected, the MAI was not correlated with any other index, although it might have some degree of relatedness with the PLI. The low correlation between the MAI and the SCI and the moderate correlation between the MAI and the EI suggests that management may not be as determinant a factor for the effective conservation of PAs.

\subsubsection{Social and economic context index (SEI)}

The territorial and demographic characteristics and trends of the Autonomous Region of Madrid provide a complex social and economic context for the PAs of the region (De Miguel and Díaz-Pineda, 2003; Naredo and
Frías, 2005). As a result, the SEI scores second lowest together with the MAI, and just after the SCI. Only one PA (NSNI Hayedo Montejo) has an "Adequate" social and economic context. Four other PAs have "Moderate" social and economic contexts: NMNI Peña Arcipreste (SEI = 1.4, near to the "Adequate" threshold), RPP Soto Henares (SEI $=1.2)$, Laguna San Juan FR (SEI = 1.0) and Peñalara NP $(\mathrm{SEI}=1.0)$. All are located in rural areas far from the metropolitan area of Madrid. In contrast, the PAs that score least in the SEI are those around the city of Madrid: Cuenca Alta RP (SEI $=0)$, Sureste RP $(\mathrm{SEI}=0)$ and Guadarrama RP (SEI $=0.3$ ). The numerous municipalities included within these PAs, the general absence of local sustainability plans in those municipalities, private ownership of land, and the negative land-use changes (Hewitt and Escobar, 2011) which have been taking place result in an unsustainable social and economic context for these PAs, which represent over $88 \%$ of the total assessed area. Reinforcing local sustainability from an ecological territorial planning perspective is, therefore, of utmost urgency in the Region (Mata et al., 2009; RodríguezRodríguez, 2012).

The SEI was negatively and significantly correlated with the TCI: a more positive social and economic context reduces the number and seriousness of threats, as expected. This index was positively and significantly correlated with the SPI, suggesting that a more positive social and economic context leads to better social perception and valuation of PAs in the Region and vice versa.

\subsubsection{Social perception and valuation index (SPI)}

The social perception and valuation of the PAs of the Autonomous Region of Madrid by residents is moderately adequate. Only two PAs, Sureste RP and Guadarrama RP, had low scores for this index due to a moderate degree of knowledge of their existence and a poor perception of their conservation state, although their scores were close to the "Moderate" threshold $(\mathrm{SPI}=0.9)$. However, only one PA: NSNI Hayedo Montejo had an "Adequate" index value (SPI $=1.7)$ as a result of the extraordinary identification with this PA by residents. The other PAs scored "Moderate" for this index. Nevertheless, the SPI is the index which scored the highest globally, indicating relevant support to nature conservation policies through PAs designation by residents in the region, as predicted in contexts of high population density and high degree of urbanization (Brotherton, 1996).

The SPI was highly and positively correlated with the SCI, implying a high degree of relatedness between the conservation state of a PA and the degree of social support for it (Borrini-Feyerabend et al., 2004; Leverington et al., 2010). This correlation suggests the potential of social sciences to estimate integrated environmental parameters without resorting necessarily to experts or to complex experimental methods, although slight differences in the results can be expected (Nolte et al., 2010). The SPI was also positively and significantly correlated with the SEI, as previously stated. 


\subsubsection{Threats to conservation index (TCI)}

The threats to the conservation of the PAs of the Autonomous Region of Madrid are generally "Moderate". Five of the ten PAs had a "Deficient" TCI due to the diversity and/or seriousness of their threats. It is of particular concern that the largest PAs are among the most threatened, with the exception of Peñalara NP, as reported previously (Rodríguez-Rodríguez, 2008). The most threatened Pas are Pinar Abantos y Herrería PL, and Regajal-Ontígola NR (TCI $=1.2$ for both). However, four PAs have an "Adequate" TCI. The least threatened PAs are NMNI Peña Arcipreste $(\mathrm{TCI}=0.4)$, and Laguna San Juan FR, PPR Soto Henares, and Peñalara NP (TCI $=0.5$ for all).

The most serious threats for the regional PAs are: "climate change" and the "presence of alien invasive species", while "Accessibility" is the third. In contrast to other findings (Rodríguez-Rodríguez, 2008; Nolte et al., 2010), recreational activities (assessed from "number of visitors" and "activities performed by visitors") have moderate or low values and are not among the main threats, although they may have serious consequences in the most popular zones (Gómez-Limón et al., 1996; Barrado, 1999). Recreational activities and climate change are recognized as the most prevalent and serious threats to European PAs (Nolte et al., 2010; Araújo et al.,2011; García-Ruiz et al., 2011).

The TCI was negatively and significantly correlated with the SEI. This suggests that the threats to the PAs of the Region of Madrid depend on the social and economic context of the region, as expected. The TCI was positively correlated with the PLI, although barely significant, which would suggest that the more a PA is threatened, the more planning has been developed to counter its threats. In contrast to what we had expected, the TCI was nonsignificantly and very weakly correlated with the SCI, implying that the variables used to build both indexes are only moderately related, at least in this study.

\subsubsection{Effectiveness index (EI)}

The overall situation of the PAs of the Autonomous Region of Madrid is ineffective. Their state of conservation, planning, management and social and economic context are generally "Deficient", with only two PAs (Peñalara NP and NSNI Hayedo Montejo) showing "Moderate" values. At the end of 2010, the other PAs were in an ineffective state, jeopardizing the aim of safeguarding regional biodiversity and related ecosystem goods and services in the long term, despite the existence of active management in some of them. This result appears to confirm that active management does not automatically lead to good conservation or to the effectiveness of a PA (Gaston et al., 2006; Araújo et al., 2011) and that context variables could determine PA effectiveness to a higher degree (Jameson et al., 2002; Rodríguez-Rodríguez and Martínez-Vega,2012).

Sureste RP, Guadarrama RP and PPR Soto Henares are the least effective PAs, with a very low EI (0.4). Four other PAs score lightly higher: Cuenca Alta RP, Pinar Abantos y Herrería PL, Regajal-Ontígola NR, and NMNI
Peña Arcipreste $(E I=0.5)$. Thus, much more should be done to ensure a sustainable future for the most important natural areas of the region of Madrid.

As the EI was made up of the six partial indexes, we had expected that all of them would be highly correlated with the EI. The partial indexes, however, made very different statistical contribution to the EI. The EI was significantly (and positively) correlated only with the SCI and with the SPI. Thus, from a statistical point of view, it cannot be affirmed that planning, management, the social and economic context (although it is close to the significant value) or the threats to the conservation of a PA influence PA effectiveness in the Region of Madrid. This statement should be considered carefully, as both the published literature and our own experience suggest that other factors (indexes) may also be relevant for the effectiveness of PAs (Hockings et al., 2006; Chape et al., 2008; Leverington et al.,2010; Nolte et al., 2010; Rodríguez-Rodríguez and Martínez-Vega,2012).

\subsection{Comparison of the two models of the SIAPA}

The results obtained with the two models were highly consistent at index level. Small shifts in values caused a maximum difference of one degree in the standard valuation of the indexes when the values were close to the cut-offs of the variables.

At index level, the valuation appeared to be slightly more positive for the SM than for the CM, although this result might well be specific to this assessment due to the exclusion of many indicators with low values from the CM.

\subsection{Validation}

Validation of the results of this study is hampered by its original focus. In the absence of previous references on PAs assessment in the region, we partially compared our results with those of a study that specifically addressed the main threats to the conservation of the PAs of the Autonomous Region of Madrid (Rodríguez-Rodríguez, 2008), in which a different assessment methodology (based on interviews to different stakeholders) was used. It may serve as a first validation test for the selection of the indicators on "Threats to conservation" and for the main results under that category. Fig. 2 shows the values from both studies, standardized to a common 0 to 10-point scale.

The standardized threat values were highly correlated in both studies $\left(\mathrm{r}=0.867^{* *}\right)$. However, the average +1.8 point valuation in the threat values in the previous study by Rodríguez-Rodríguez (2008) $(\mathrm{t}=-6.34$; $\mathrm{p}<0.000)$ appears to corroborate that threat indexes to PAs based on perceptions score higher than threat indexes based on more experimental techniques, as suggested by Nolte et al. (2010).

The overall degree of threat for each of the 10 PAs was partially consistent in both studies. According to the SIAPA, the most threatened PAs were, in decreasing order: Pinar Abantos y Herrería PL, and Regajal- Ontígola 
$\mathrm{NR}(\mathrm{TCI}=1.2$ for both$)$, and Guadarrama RP, Sureste RP and Cuenca Alta RP, all with a TCI of 1.0. According to the previous study, the decreasing order of threat was: Sureste RP, Pinar Abantos Herrería PL, Regajal- Ontígola NR, and Cuenca Alta del Manzanares RP, being the Curso Medio del Río Guadarrama y su entorno RP, which had a moderately high degree of threat by the SIAPA, the most threatened PA (Rodríguez-Rodríguez, 2008). In addition, seven of the nine major threats to PAs perceived by stakeholders in the 2008 study (except "water pollution" and "mining") were also selected as the main threats to the effectiveness of Pas from the original indicators list of the SIAPA by the expert panel(Rodríguez-Rodríguez and Martínez-Vega, 2012).

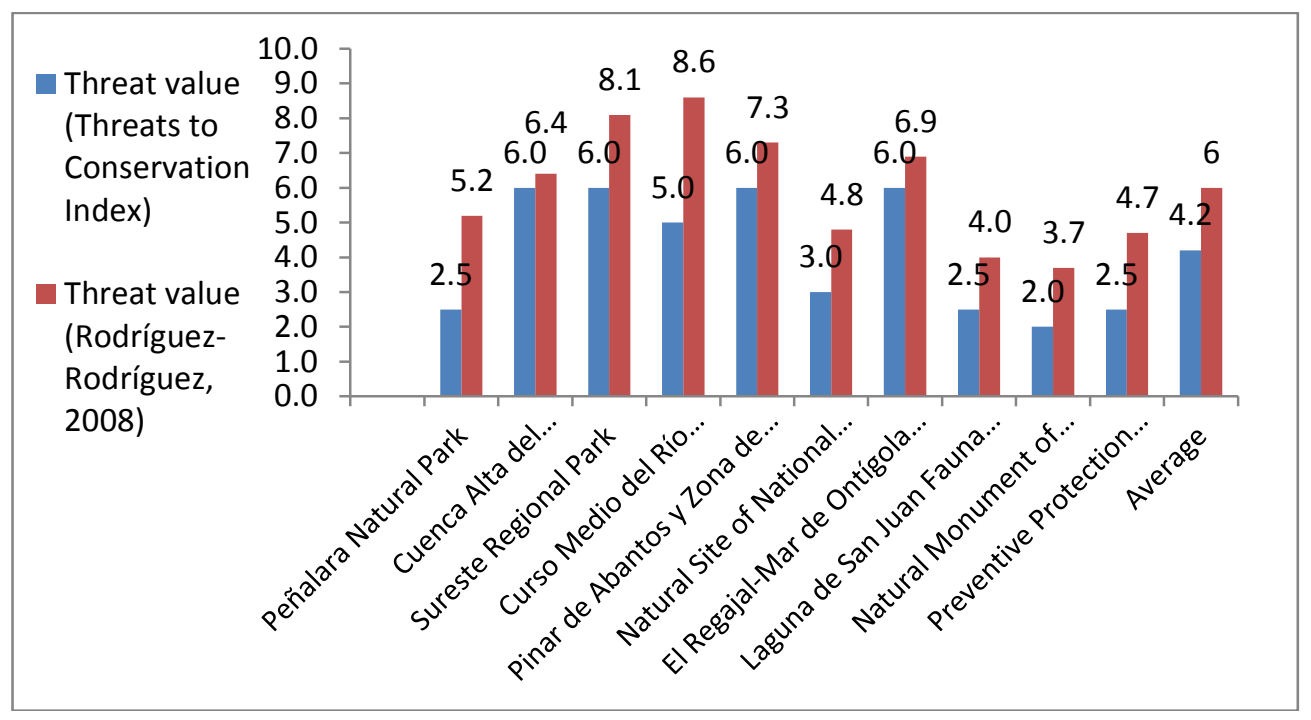

Fig. 2. Protected area threat values in two studies.

\section{Conclusions: lessons learned in developing and implementing the SIAPA}

The results from both models of the SIAPA are highly consistent. However, once one model is chosen for a PA or group of PAs, the same model should be used repeatedly in future assessments, as aggregated results (indexes) from both models are not directly comparable (Rodríguez-Rodríguez and Martínez-Vega, 2012). The statistical techniques used to assess the degree of relatedness among indicators and between these and the indexes did not prove useful to simplify the SIAPA. Results showed inconsistent, random relationships among variables (indicators and indexes) that could be due to the low number of cases $(n=10)$ or to the few values that standardized variables could take.

The development of the SIAPA, the testing of other simplified models (SM plus other models further simplified but discarded for incomplete) and their implementation in 10 pilot PAs, including reporting and communication, required about 2 years of work, a trained assessing staff of two people, and an approximate direct cost of 30,000D , which covered one full-time pre-doctoral contract for 2 years. On the basis of the main structure of any of the existing SIAPA models (with the necessary adaptations and improvements), new assessments could be conducted in the Region of Madrid or in other Spanish or international PAs within a few months and at a fraction of the above cost. The time and cost of the assessment will, however, depend on the number of PAs assessed, the amount of information available and the qualifications and experience of the assessors. Considering the previous remarks, it can be inferred that the $35 \%$ reduction in the number of indicators assessed in the SM could lead to a similar reduction of the costs and time needed to implement it when compared with the CM.

Participation in the development and implementation of the SIAPA was wider than in most PA assessments worldwide (Chape et al., 2008), although the voluntary nature of the participation limited further involvement (Spangenberg, 2011). The participants included scientists, PAs managers, state agencies, environmental NGOs and local populations.

The fact that the assessment was conducted by an institution external to the Regional Ministry of Environment ensured the independence of the assessment (Paleczny and Russell, 2005). Often, however, this fact made it difficult to obtain data due to misunder-standing and mistrust towards the "audit" as a result of a lack of a culture of evaluation, transparency and accountability in the Spanish public sector. In contrast to the positive and useful opinion of PA assessments by most managers (Paleczny and Russell, 2005), the main constraints in developing the SIAPA in the Autonomous Region of Madrid were the poor enthusiasm and cooperation with the assessment by some of the regional administration staff (others cooperated quite happily), and also the scarcity, availability and dispersion of basic information. These 
limitations are common in PA assessments (Paleczny and Russell, 2005; Gaston et al., 2006; Bertzky and StollKleemann, 2009; Nolte et al., 2010). Nevertheless, lack of basic information was not a key constraint for the implementation of the SIAPA, as only 3 of the 43 indicators could not be assessed for this reason: "Sanctioning procedures", "Main economic activities in the PA", and "Evolution of the feature/s for which the PA was designated". Evaluating whether Pas values are being conserved is one of the most challenging aspects of such assessments (Nolte et al., 2010), mainly because of the absence or vagueness of conservation and management objectives (Naughton-Treves et al., 2005). Some improvements in the type of data and the manner in which they are collected would be desirable to be able to collect the information for these 3 indicators in the future (Ramírez, 2002; Paleczny and Russell,2005).

The environmental and scientific knowledge of the PA managers of the Region of Madrid, especially other than Park's directors, should be improved so that future management decisions are based on sound science, as current deficiencies in knowledge limit effective management and hinder evaluation. Such deficiencies in specialized knowledge and training among PAs managers are common in Europe (Nolte et al., 2010) and elsewhere, despite their importance for effective management (Leverington et al., 2010).

In summary, the SIAPA showed useful for identifying the strengths and weaknesses related to the effectiveness of the Pas of the Autonomous Region of Madrid. Its integrated nature makes it useful for PA managers and scientists, whereas its comparability provides an added value especially for PA network managers and policymakers. It can potentially be used and adapted to a wide range of PAs and contexts (Rodríguez-Rodríguez and Martínez-Vega, 2012), as long as a minimum amount of resources and enough basic information are provided. It needs, however, institutional support to be fully effective.

This first assessment of the PAs of the Autonomous Region of Madrid provides the most complete, up-to-date, accurate information on the state of each PA in the region. It is now up to the regional authorities to take the necessary measures to improve the effectiveness of the PAs of the region from a territorial perspective (Mata et al., 2009), as improving conservation should be the ultimate goal of any PA assessment (Ervin, 2003; Bertzky and Stoll-Kleemann,2009).

\section{Acknowledgements}

The authors would like to thank everyone who contributed somehow to this paper: David Riaño and José Manuel Rojo, of the Spanish National Research Council, and Alain Jeudy de Grissac, of the IUCN Centre for Mediterranean Cooperation, for their useful comments on the early drafts of this paper; Jorge Morales, also of the Spanish National Research Council, for his help with the artwork, and Elizabeth Heseltine for her useful remarks on the final draft of this paper. We would also like to acknowledge the expert panel and all the people of the different institutions and administrations who collaborated by providing data and advice to conduct the assessment, especially the staff of the Regional Ministry of Environment of the Autonomous Region of Madrid. Finally, we would like to thank the anonymous reviewers who contributed to enhance the quality of this manuscript.

This study was funded by a JAE doctoral Grant by the Spanish National Research Council.

\section{Appendix A. Supplementary data}

Supplementary data associated with this article can befound, in the online version, at

http://dx.doi.org/10.1016/j.ecolind.2013.04.019.

\section{References}

Araújo, M.B., Alagador, D., Cabeza, M., Nogués-Bravo, D., Thuiller, W., 2011. Climate change threatens European conservation areas. Ecol. Lett. 14, 484-492.

Barrado, D.A., 1999. Actividades de ocio y recreativas en el medio natural de la Comunidad de Madrid. Consejería de Medio Ambiente. Comunidad de Madrid, Madrid.

Bertzky, M., Stoll-Kleemann, S., 2009. Multi-level discrepancies with sharing data on protected areas: what we have and what we need for the global village. J. Environ. Manage. 90, 8-24.

Borrini-Feyerabend, G., Kothary, A., Oviedo, G., 2004 Indigenous and Local Communities and Protected Areas: Towards Equity and Enhanced Conservation. IUCN, Gland, Switzerland, and Cambridge, UK.

Brotherton, I., 1996. Protected area theory at the system level. J. Environ. Manage. 47, 369-379.

CBD Convention on Biological Diversity, 1992. Text of the CBD, http://www.cbd.int/convention/text/ (accessed 01.13).

CBD Convention on Biological Diversity, 2004. Programme of Work on Protected Areas, http://www.cbd.int/ protected/pow/learnmore/intro/ (accessed 12.12).

CBD Convention on Biological Diversity, 2010. COP 10. Decision X/31. Protected areas, http://www.cbd.int/ decision/cop/?id=12297 (accessed 01.13).

Chape, S., Spalding, M., Jenkins, M.D., 2008. The World's Protected Areas: Status, Values and Prospects in the 21st Century. Prepared by the UNEP World Conservation Monitoring Centre. University of California Press, Berkeley, USA.

Chicharro, E., 1976. Application of Landsat-2 data to land use mapping in Central Spain. In: Nunez, R. (Ed.), Thematic Mapping, Land Use, Geological Structure and Water Resources in Central Spain. NASA project 28760, Madrid, Spain, pp.216-219.

De Miguel, J.M., y Díaz-Pineda, F., 2003. Medio ambiente. Problemas y posibilidades. In: García-Delgado, J.L. (Ed.), Estructura económica de Madrid. , 2nd ed. Consejería de Justicia e Innovación Tecnológica. Comunidad de Madrid, Madrid.

Delgado, C., 2008. Urbanización sin fronteras" El acoso urbanístico a los espacios naturales protegidos. Bol. AGE 47, 271-310.

Díaz-Muñoz, M.A., 1984. Criterios para el análisis de la evolución de usos del suelo en zona de montaña: aplicación a un sector de Somosierra. Ann. Geogr. 4,131-147.

Ervin, J., 2003. Protected area assessment in perspective. BioScience 53, 819-822.

Europarc-España, 2002. Plan de Acción para los espacios naturales protegidos del Estado español. FUNGOBE, Madrid. 
Europarc-Spain, 2009. Work Programme for Protected Areas 2009-2013. FUNGOBE, Madrid.

Fernández-Muñoz, S., 2008. Participación pública, gobierno del territorio y paisaje en la Comunidad de Madrid. Bol. AGE N 46, 97-119.

Fraser, E.D.G., Dougill, A.J., Mabee, W.E., Reed, M., McAlpine, P., 2006. Bottom up and top down: Analysis of participatory processes for sustainability indicator identification as a pathway to community empowerment and sustainable environmental management. J. Environ. Manage. 78, 114127.

Gago, C., Serrano, M., Antón, F.J., 2004. Repercusiones de las carreteras orbitales de la Comunidad de Madrid en los cambios de usos del suelo. Ann. Geogr. 24,145-167.

Gallardo, M., Martínez-Vega, J.,2010. Detecting land use change in Madrid, Spain, using Corine Land Cover maps. In: Ester Boserup Conference. A centenal tribute. Long-term trajectories in population, gender relations, land use and the environment. Alpen Adria Universitaet, Vienna.

Gallardo, M., Martínez-Vega, J.,2012. Cambios de usos del suelo en la Comunidad de Madrid: analizando el pasado y simulando el futuro. In: XV Congreso Nacional de Tecnologías de Información Geográfica. AGE-CSIC, Madrid.

García-Ruiz, J.M., López-Moreno, J.I., Vicente-Serrano, S.M., Lasanta-Martínez, T., Beguería, S., 2011. Mediterranean water resources in a global change scenario.Earth-Sci. Rev. 105, 121-139.

Gaston, K.J., Charman, K., Jackson, S.F., Armsworth, P.R., Bonn, A., Briers, R.A.,Callaghan, C.S.Q., Catchpole, R., Hopkins, J., Kunin, W.E., Latham, J., Opdam,P., Stoneman, R., Stroud, D.A., Tratt, R., 2006. The ecological effectiveness of protected areas: the United Kingdom. Biol. Conserv. 132, 76-87.

Gómez-Limón, J., Múgica, M., Muñoz, C., y De Lucio, J.V., 1996. Uso recreativo de los espacios naturales en Madrid. In: Frecuentación, caracterización de visitantes e impactos ambientales. Serie Documentos, n॰19. Centro de Investigación "Fernando González Bernáldez". Soto del Real, Spain.

Gutiérrez, A., 1998. Cambios de usos del suelo y modelos de organización espacial de un paisaje de montaña mediterránea. El valle del Lozoya (Sistema Central, Madrid). Universidad Autónoma de Madrid, Madrid.

Hewitt, R., Escobar, F., 2011. The territorial dynamics of fastgrowing regions: unsustainable land use change and future policy challenges in Madrid, Spain. Appl. Geogr. 31, 650667

Hockings, M., Stolton, S., Leverington, F., Dudley, N., Courrau, J., 2006. Evaluating effectiveness. A framework for assessing management effectiveness of protected areas, 2nd ed. IUCN, Gland, Switzerland, and Cambridge, UK.

INE Instituto Nacional de Estadística, 2012. INE base. Demografía y Población. Cifras de población y Censos demográficos, http://www.ine.es/inebmenu/mnu cifraspob. htm (accessed 12.12).

Jameson, S.C., Tupper, M.H., Ridley, J.M., 2002. The three screen doors: Can marine 'protected' areas be effective? Mar. Pollut. Bull. 44, 1177-1183.

Jongman, R.H.G., 2002. Homogeneisation and fragmentation of the European landscape: ecological consequences and solutions. Landsc. Urban Plan. 58,211-221.

Leverington, F., Lemos, K., Courrau, J., Pavese, H., Nolte, C., Marr, M., Coad, L.,Burguess, N., Bomhard, B., Hockings, M., 2010. Management effectiveness evaluation in protected areas - a global study, 2nd ed. University of Queensland, Brisbane, Australia.

Mata, R., Galiana, L., Allende, F., Fernández, S., Lacasta, P., López, N., Molina, P., Sanz,C., 2009. Evaluación del paisaje de la Comunidad de Madrid: de la protección a la gestión territorial. Urban 14, 34-57.

Naredo, J.M.,2008. Cambios y tendencias de la ocupación del suelo en la Comunidad de Madrid (1956-1986-2005). In: La evolución de los usos del suelo en Madrid. Consejería de Ordenación del Territorio y Medio Ambiente, Madrid.

Naredo, J.M., Frías, F., 2005. Desarrollo: la síntesis del «desarrollo sostenible» con especial referencia a la Comunidad de Madrid. In: Sánchez-Herrera, F. (Ed.), Cuartas Jornadas Científicas del Parque Natural de Peñalara y del Valle de El Paular. Conservación y desarrollo socioeconómico en Espacios Naturales Protegidos Consejería de Medio Ambiente y Ordenación del Territorio, Comunidad de Madrid, Madrid.

Naredo, J.M., García-Zaldívar, R., 2008. Estudio sobre la ocupación del suelo por usos urbano-industriales, aplicado a la Comunidad de Madrid. UPM-Ministerio de Medio Ambiente, Madrid.

Naughton-Treves, L., Buck, M., Brandon, K., 2005. The role of protected areas in conserving biodiversity and sustaining local livelihoods. Annu. Rev. Environ. Resour.30, 219-252.

Nolte, C., Leverington, F., Kettner, A., Marr, M., Nielsen, G., Bomhard, B., Stolton,S., Stoll-Kleemann, S., Hockings, M 2010. Protected Area Management Effectiveness Assessments in Europe. A Review of Application, Methods and Results. University of Greifswald, Germany.

Paleczny, D.R., Russell, S., 2005. Participatory approaches in protected area assessment and reporting. In: Proceedings of the Parks Research Forum of Ontario, University of Guelph, Canada

Pérez-Hugalde, C., Romero-Calcerrada, R., Delgado-Pérez, P., Novillo, C.J., 2011.Understanding land cover change in a Special Protection Area in Central Spain through the enhanced land cover transition matrix and a related new approach.J. Environ. Manage. 92, 1128-1137.

Pomeroy, R.S., Watson, L.M., Parks, J.E., Cid, G.A., 2005. How is your MPA doing? A methodology for evaluating the management effectiveness of marine protected areas. Ocean Coast. Manage. 48, 485-502.

Radeloff, V.C., Stewart, S.I., Hawbaker, T.J., Gimmi, U., Pidgeon, A.M., Flather, C.H.,Hammer, R.B., Helmers, D.P., 2010. Housing growth in and near United States protected areas limits their conservation value. Proc. Natl. Acad. Sci. $107,940-945$

Ramírez, L., 2002. Indicadores ambientales. Una visión general In: Ramírez, L. (Ed.),Indicadores ambientales. Situación actual y perspectivas. Organismo Autónomo Parques Nacionales, Madrid.

Rodríguez-Rodríguez, D., 2008. Los espacios naturales protegidos de la Comunidad de Madrid. In: Principales amenazas para su conservación. Edito-rial Complutense, Madrid, http://www.ucm.es/BUCM/ecsa/36254.php?id= 187(accessed 12.12)

Rodríguez-Rodríguez, D., 2012. Integrated networks. A territorial planning proposal for biodiversity conservation in urban, densely populated regions. The case of the Autonomous Region of Madrid, Spain. J. Environ. Plan. Manage. 55, 667-683.

Rodríguez-Rodríguez, D., Martínez-Vega, J., 2012. Proposal of a system for the integrated and comparative assessment of protected areas. Ecol. Indic. 23, 566-572.

Spangenberg, J.H., 2011. Sustainability science: a review, an analysis and some empirical lessons. Environ. Conserv. 38, 275-287.

VVAA, 2005. Sostenibilidad en España 2005. In: Informe de Primavera. Observatorio de la Sostenibilidad de España. Alcalá de Henares, Spain. 


\section{Results per protected area}

\begin{tabular}{|c|c|c|c|c|c|}
\hline \multicolumn{6}{|c|}{ Peñalara Natural Park } \\
\hline \multicolumn{6}{|c|}{ Area (ha.): 11637} \\
\hline \multicolumn{4}{|l|}{ Designation date: 1990} & \multicolumn{2}{|c|}{ Assessment date: $2009-10$} \\
\hline Assessment number: 1 & & Period & city of asse & ssment: Every & ive years \\
\hline Index / Indicator & Valuation & State & Tendency & $\begin{array}{c}\text { Measurement } \\
\text { period }\end{array}$ & Remarks \\
\hline State of Conservation & 1 & $(9)$ & & & \\
\hline $\begin{array}{l}\text { Evolution of populations of } \\
\text { endangered species or } \\
\text { subspecies }\end{array}$ & 0 & (8) & NA & $1989-2008$ & \\
\hline Health of vegetation & 1 & $(9)$ & $\uparrow$ & $2002-2009$ & \\
\hline Surface water quality & 2 & (:) & NA & 2008 & \\
\hline Air quality & 2 & (:) & NA & 2008 & \\
\hline Presence of solid waste & 1 & $(9)$ & NA & 2009 & \\
\hline Landscape impact & 2 & (:) & NA & 2009 & \\
\hline Planning & 2 & (ن) & & & \\
\hline $\begin{array}{l}\text { Appropriateness of protection } \\
\text { legislation }\end{array}$ & 2 & (:) & $\leftrightarrow$ & $1990-2009$ & \\
\hline $\begin{array}{l}\text { Existence of updated planning } \\
\text { documents }\end{array}$ & 2 & (:) & $\uparrow$ & $1990-2009$ & \\
\hline $\begin{array}{l}\text { Existence of updated documents } \\
\text { on social and economic } \\
\text { development }\end{array}$ & 1 & $(-)$ & $\uparrow$ & 1990-2009 & \\
\hline $\begin{array}{l}\text { Existence of updated } \\
\text { management documents }\end{array}$ & 1 & $(-)$ & $\uparrow$ & $1990-2009$ & \\
\hline $\begin{array}{l}\text { Existence of updated documents } \\
\text { on public use }\end{array}$ & 1 & (9) & $\uparrow$ & $1990-2009$ & \\
\hline Zoning & 2 & (:) & $\uparrow$ & $1990-2009$ & \\
\hline $\begin{array}{l}\text { Evolution of the area designated } \\
\text { as protected }\end{array}$ & 2 & (:) & $\uparrow$ & $1990-2009$ & \\
\hline Management & 2 & (:) & & & \\
\hline $\begin{array}{l}\text { Degree of characterization of the } \\
\text { protected area }\end{array}$ & 2 & (:) & $\uparrow$ & $1990-2009$ & \\
\hline $\begin{array}{l}\text { Degree of fulfillment of } \\
\text { management objectives }\end{array}$ & 2 & (:) & NA & 2008 & \\
\hline $\begin{array}{l}\text { Evolution of feature(s) for which } \\
\text { the protected area was } \\
\text { designated }\end{array}$ & ¿? & & & & \\
\hline $\begin{array}{l}\text { Existence of sufficient } \\
\text { management staff }\end{array}$ & 2 & (:) & NA & 2005 & \\
\hline $\begin{array}{l}\text { Evolution of investment in the } \\
\text { protected area }\end{array}$ & 2 & (:) & $\downarrow$ & $2002-2009$ & \\
\hline $\begin{array}{l}\text { Effectiveness of public } \\
\text { participation bodies }\end{array}$ & 0 & (8) & $\leftrightarrow$ & $1990-2009$ & \\
\hline $\begin{array}{l}\text { Production and distribution of an } \\
\text { annual report on activities and } \\
\text { outcomes }\end{array}$ & 2 & (:) & $\leftrightarrow$ & 1999-2009 & \\
\hline $\begin{array}{l}\text { Easiness to identify the protected } \\
\text { area }\end{array}$ & 0 & (8) & NA & 2009 & \\
\hline
\end{tabular}




\begin{tabular}{|c|c|c|c|c|}
\hline Public use infrastructure & 1 & 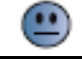 & NA & 2009 \\
\hline $\begin{array}{l}\text { Existence of environmental } \\
\text { education and volunteering } \\
\text { activities }\end{array}$ & 2 & (:) & $\uparrow$ & 1990-2009 \\
\hline Sanctioning procedures & ¿? & & & \\
\hline Monitoring activities & 2 & (:) & $\uparrow$ & 1990-2009 \\
\hline Social and Economic Context & 1 & $(-)$ & & \\
\hline $\begin{array}{l}\text { Number of municipalities in the } \\
\text { protected area }\end{array}$ & 2 & (:) & $\leftrightarrow$ & $1990-2009$ \\
\hline $\begin{array}{l}\text { Area provided for the protected } \\
\text { area by municipalities under local } \\
\text { Agenda } 21\end{array}$ & 0 & (8) & $\leftrightarrow$ & $1990-2008$ \\
\hline Land ownership & 1 & (9) & NA & 2005 \\
\hline $\begin{array}{l}\text { Main economic activities in the } \\
\text { protected area }\end{array}$ & ¿? & & & \\
\hline Land use changes & 1 & $(-)$ & $\leftrightarrow$ & $1990 ; 2000$ \\
\hline $\begin{array}{l}\text { Social Perception and } \\
\text { Valuationl }\end{array}$ & 1 & (:) & & \\
\hline $\begin{array}{l}\text { Degree of knowledge on the } \\
\text { protected area }\end{array}$ & 2 & (:) & $\uparrow$ & $2007 ; 2009$ \\
\hline $\begin{array}{l}\text { Perception of the conservation } \\
\text { state }\end{array}$ & 2 & (:) & $\uparrow$ & $2007 ; 2009$ \\
\hline Personal importance & 2 & (:) & $\uparrow$ & $2007 ; 2009$ \\
\hline $\begin{array}{l}\text { Economic valuation of the } \\
\text { protected area }\end{array}$ & 0 & (8) & $\uparrow$ & $2007 ; 2009$ \\
\hline Threats to Conservation & 0 & (:) & & \\
\hline $\begin{array}{l}\text { Presence of alien invasive } \\
\text { species }\end{array}$ & 2 & (8) & NA & 2009 \\
\hline Climate change & 1 & $(\bullet)$ & NA & $1972-2003$ \\
\hline Area affected by fires & 0 & (:) & $\leftrightarrow$ & $2000-2008$ \\
\hline Fragmentation & 0 & (:) & NA & 2000 \\
\hline Isolation & 0 & (:) & $\leftrightarrow$ & $1990 ; 2000$ \\
\hline Accessibility & 0 & (:) & NA & 2009 \\
\hline Number of visitors & 1 & $(9)$ & $\downarrow$ & $1997-2008$ \\
\hline Activities performed by visitors & 0 & (:) & NA & 2009 \\
\hline Local population density & 0 & (5) & $\downarrow$ & $1990-2008$ \\
\hline Effectiveness & 1 & $(-)$ & & \\
\hline
\end{tabular}

Table 1. Results for Peñalara Natural Park 
Cuenca Alta del Manzanares Regional Park

Area (ha.): 52796

\begin{tabular}{|c|c|c|c|c|c|}
\hline \multicolumn{2}{|l|}{ Designation date: 1985} & \multicolumn{4}{|c|}{ Assessment date: $2009-10$} \\
\hline Assessment number: 1 & & Perioc & city of asse & ssment: Every & ive years \\
\hline Index / Indicator & Valuation & State & Tendency & $\begin{array}{c}\text { Measurement } \\
\text { period }\end{array}$ & Remarks \\
\hline State of Conservation & 0 & (8) & & & \\
\hline $\begin{array}{l}\text { Evolution of populations of } \\
\text { endangered species or } \\
\text { subspecies }\end{array}$ & 0 & (8) & NA & $1992-2008$ & \\
\hline Health of vegetation & 1 & $(9)$ & $\downarrow$ & $2002-2009$ & \\
\hline Surface water quality & 2 & (:) & NA & 2008 & \\
\hline Air quality & 0 & (8) & NA & 2008 & \\
\hline Presence of solid waste & 1 & (9) & NA & 2009 & \\
\hline Landscape impact & 1 & $(9)$ & NA & 2009 & \\
\hline Planning & 0 & (8) & & & \\
\hline $\begin{array}{l}\text { Appropriateness of protection } \\
\text { legislation }\end{array}$ & 2 & (4) & $\leftrightarrow$ & $1985-2009$ & \begin{tabular}{|l|} 
Part of its \\
area was \\
declared \\
Natural \\
Site of \\
National \\
Interest in \\
1930 \\
\end{tabular} \\
\hline $\begin{array}{l}\text { Existence of updated planning } \\
\text { documents }\end{array}$ & 0 & (8) & $\leftrightarrow$ & $1985-2009$ & \\
\hline $\begin{array}{l}\text { Existence of updated documents } \\
\text { on social and economic } \\
\text { development }\end{array}$ & 0 & (8) & $\leftrightarrow$ & $1985-2009$ & \\
\hline $\begin{array}{l}\text { Existence of updated } \\
\text { management documents }\end{array}$ & 1 & () & $\uparrow$ & $1985-2009$ & \\
\hline $\begin{array}{l}\text { Existence of updated documents } \\
\text { on public use }\end{array}$ & 1 & (-) & $\uparrow$ & $1985-2009$ & \\
\hline Zoning & 1 & (9) & $\leftrightarrow$ & $1985-2009$ & \\
\hline $\begin{array}{l}\text { Evolution of the area designated } \\
\text { as protected }\end{array}$ & 2 & (:) & $\uparrow$ & $1985-2009$ & \\
\hline Management & 1 & (-) & & & \\
\hline $\begin{array}{l}\text { Degree of characterization of the } \\
\text { protected area }\end{array}$ & 2 & (4) & $\uparrow$ & $1985-2009$ & \\
\hline $\begin{array}{l}\text { Degree of fulfillment of } \\
\text { management objectives }\end{array}$ & 2 & (ب) & NA & 2008 & \\
\hline $\begin{array}{l}\text { Evolution of feature(s) for which } \\
\text { the protected area was } \\
\text { designated } \\
\end{array}$ & ¿? & & & & \\
\hline $\begin{array}{l}\text { Existence of sufficient } \\
\text { management staff }\end{array}$ & 2 & (:) & NA & 2005 & \\
\hline $\begin{array}{l}\text { Evolution of investment in the } \\
\text { protected area }\end{array}$ & 0 & (2) & $\uparrow$ & $2002-2009$ & \\
\hline $\begin{array}{l}\text { Effectiveness of public } \\
\text { participation bodies }\end{array}$ & 0 & (8) & $\uparrow$ & $1985-2009$ & \\
\hline
\end{tabular}




\begin{tabular}{|c|c|c|c|c|c|}
\hline $\begin{array}{l}\text { Production and distribution of an } \\
\text { annual report on activities and } \\
\text { outcomes }\end{array}$ & 2 & & $\leftrightarrow$ & 1999-2009 & \\
\hline $\begin{array}{l}\text { Easiness to identify the protected } \\
\text { area }\end{array}$ & 0 & & NA & 2009 & \\
\hline Public use infrastructure & 1 & 光) & NA & 2009 & \\
\hline $\begin{array}{l}\text { Existence of environmental } \\
\text { education and volunteering } \\
\text { activities }\end{array}$ & 2 & & $\uparrow$ & $1985-2009$ & \\
\hline Sanctioning procedures & ¿? & & & & \\
\hline Monitoring activities & 1 & (9) & $\uparrow$ & 1985-2009 & \\
\hline Social and Economic Context & 0 & & & & \\
\hline $\begin{array}{l}\text { Number of municipalities in the } \\
\text { protected area }\end{array}$ & 0 & & NA & 2009 & \\
\hline $\begin{array}{l}\text { Area provided for the protected } \\
\text { area by municipalities under local } \\
\text { Agenda } 21\end{array}$ & 0 & & $\uparrow$ & $1985-2009$ & \\
\hline Land ownership & 0 & (8) & NA & 2005 & \\
\hline $\begin{array}{l}\text { Main economic activities in the } \\
\text { protected area }\end{array}$ & ¿? & & & & \\
\hline Land use changes & 0 & (8) & $\downarrow$ & $1990 ; 2000$ & \\
\hline $\begin{array}{l}\text { Social Perception and } \\
\text { Valuationl }\end{array}$ & 1 & & & & \\
\hline $\begin{array}{l}\text { Degree of knowledge on the } \\
\text { protected area }\end{array}$ & 2 & & $\uparrow$ & $2007 ; 2009$ & \\
\hline $\begin{array}{l}\text { Perception of the conservation } \\
\text { state }\end{array}$ & 0 & & $\downarrow$ & $2007 ; 2009$ & \\
\hline Personal importance & 2 & & $\downarrow$ & $2007 ; 2009$ & \\
\hline $\begin{array}{l}\text { Economic valuation of the } \\
\text { protected area }\end{array}$ & 1 & & $\downarrow$ & $2007 ; 2009$ & \\
\hline Threats to Conservation & 2 & & & & \\
\hline Presence of alien invasive species & 2 & & NA & 2009 & \\
\hline Climate change & 2 & & NA & $1972-2003$ & \\
\hline Area affected by fires & 0 & & $\downarrow$ & $2000-2008$ & \\
\hline Fragmentation & 1 & & NA & 2000 & \\
\hline Isolation & 1 & & $\downarrow$ & $1990 ; 2000$ & \\
\hline Accessibility & 2 & & NA & 2009 & \\
\hline Number of visitors & 0 & & $\uparrow$ & $1997-2008$ & \\
\hline Activities performed by visitors & 0 & & NA & 2009 & \\
\hline Local population density & 2 & & $\leftrightarrow$ & $1985-2008$ & \\
\hline Effectiveness & 0 & & & & \\
\hline
\end{tabular}

Table 2. Results for Cuenca Alta del Manzanares Regional Park 
Sureste Regional Park

Area (ha.): 31550

\begin{tabular}{|c|c|c|c|c|c|}
\hline \multirow{2}{*}{\multicolumn{2}{|c|}{$\begin{array}{l}\text { Designation date: } 1994 \\
\text { Assessment number: } 1 \\
\end{array}$}} & \multicolumn{4}{|c|}{ Assessment date: $2009-10$} \\
\hline & & Perio & city of asse & ssment: Every & ive years \\
\hline Index / Indicator & Valuation & State & Tendency & $\begin{array}{c}\text { Measurement } \\
\text { period }\end{array}$ & Remarks \\
\hline State of Conservation & 0 & (8) & & & \\
\hline $\begin{array}{l}\text { Evolution of populations of } \\
\text { endangered species or } \\
\text { subspecies }\end{array}$ & 0 & (8) & NA & $1994-2008$ & \\
\hline Health of vegetation & 1 & (9) & $\downarrow$ & $2002-2009$ & \\
\hline Surface water quality & 0 & (8) & $\downarrow$ & $2004 ; 2008$ & \\
\hline Air quality & 0 & (8) & NA & 2008 & \\
\hline Presence of solid waste & 0 & (8) & NA & 2009 & \\
\hline Landscape impact & 0 & (8) & NA & 2009 & \\
\hline Planning & 1 & $(9)$ & & & \\
\hline $\begin{array}{l}\text { Appropriateness of protection } \\
\text { legislation }\end{array}$ & 2 & (:) & $\leftrightarrow$ & 1994-2009 & \\
\hline $\begin{array}{l}\text { Existence of updated planning } \\
\text { documents }\end{array}$ & 1 & $(-)$ & $\uparrow$ & 1994-2009 & \\
\hline $\begin{array}{l}\text { Existence of updated documents } \\
\text { on social and economic } \\
\text { development }\end{array}$ & 1 & $(9)$ & $\uparrow$ & 1994-2009 & \\
\hline $\begin{array}{l}\text { Existence of updated } \\
\text { management documents }\end{array}$ & 2 & (:) & $\uparrow$ & 1994-2009 & \\
\hline $\begin{array}{l}\text { Existence of updated documents } \\
\text { on public use }\end{array}$ & 1 & $(9)$ & $\uparrow$ & 1994-2009 & \\
\hline Zoning & 1 & (9) & $\leftrightarrow$ & 1994-2009 & \\
\hline $\begin{array}{l}\text { Evolution of the area designated } \\
\text { as protected }\end{array}$ & 2 & (:) & $\uparrow$ & $1994-2009$ & \\
\hline Management & 1 & (2) & & & \\
\hline $\begin{array}{l}\text { Degree of characterization of the } \\
\text { protected area }\end{array}$ & 1 & (9) & $\uparrow$ & 1994-2009 & \\
\hline $\begin{array}{l}\text { Degree of fulfillment of } \\
\text { management objectives }\end{array}$ & 2 & (ن) & NA & 2008 & \\
\hline $\begin{array}{l}\text { Evolution of feature(s) for which } \\
\text { the protected area was } \\
\text { designated }\end{array}$ & ¿? & & & & \\
\hline $\begin{array}{l}\text { Existence of sufficient } \\
\text { management staff }\end{array}$ & 2 & (:) & NA & 2005 & \\
\hline $\begin{array}{l}\text { Evolution of investment in the } \\
\text { protected area }\end{array}$ & 0 & (2) & $\downarrow$ & $2002-2009$ & \\
\hline $\begin{array}{l}\text { Effectiveness of public } \\
\text { participation bodies }\end{array}$ & 0 & (2) & $\leftrightarrow$ & 1994-2009 & \\
\hline $\begin{array}{l}\text { Production and distribution of an } \\
\text { annual report on activities and } \\
\text { outcomes }\end{array}$ & 2 & (4) & $\leftrightarrow$ & 1999-2009 & \\
\hline $\begin{array}{l}\text { Easiness to identify the protected } \\
\text { area }\end{array}$ & 0 & (8) & NA & 2009 & \\
\hline Public use infrastructure & 1 & (9) & NA & 2009 & \\
\hline
\end{tabular}




\begin{tabular}{|c|c|c|c|c|}
\hline $\begin{array}{l}\text { Existence of environmental } \\
\text { education and volunteering } \\
\text { activities }\end{array}$ & 2 & & & 1994-2009 \\
\hline Sanctioning procedures & ¿? & & & \\
\hline Monitoring activities & 1 & (1) & $\uparrow$ & 1994-2009 \\
\hline Social and Economic Context & 0 & (8) & & \\
\hline $\begin{array}{l}\text { Number of municipalities in the } \\
\text { protected area }\end{array}$ & 0 & (2) & NA & 2009 \\
\hline $\begin{array}{l}\text { Area provided for the protected } \\
\text { area by municipalities under local } \\
\text { Agenda } 21\end{array}$ & 0 & & $\uparrow$ & 1994-2009 \\
\hline Land ownership & 0 & (8) & NA & 2005 \\
\hline $\begin{array}{l}\text { Main economic activities in the } \\
\text { protected area }\end{array}$ & ¿? & & & \\
\hline Land use changes & 0 & & $\downarrow$ & $1990 ; 2000$ \\
\hline $\begin{array}{l}\text { Social Perception and } \\
\text { Valuationl }\end{array}$ & 0 & & & \\
\hline $\begin{array}{l}\text { Degree of knowledge on the } \\
\text { protected area }\end{array}$ & 1 & & $\downarrow$ & $2007 ; 2009$ \\
\hline $\begin{array}{l}\text { Perception of the conservation } \\
\text { state }\end{array}$ & 0 & & $\downarrow$ & $2007 ; 2009$ \\
\hline Personal importance & 2 & & $\uparrow$ & $2007 ; 2009$ \\
\hline $\begin{array}{l}\text { Economic valuation of the } \\
\text { protected area }\end{array}$ & 1 & & 1 & $2007 ; 2009$ \\
\hline Threats to Conservation & 2 & & & \\
\hline $\begin{array}{l}\text { Presence of alien invasive } \\
\text { species }\end{array}$ & 2 & & NA & 2009 \\
\hline Climate change & 2 & & NA & $1972-2003$ \\
\hline Area affected by fires & 0 & & $\uparrow$ & $2000-2008$ \\
\hline Fragmentation & 1 & (9) & NA & 2000 \\
\hline Isolation & 1 & (19) & $\downarrow$ & $1990 ; 2000$ \\
\hline Accessibility & 2 & & NA & 2009 \\
\hline Number of visitors & 0 & (4) & $\downarrow$ & $1997-2008$ \\
\hline Activities performed by visitors & 0 & & NA & 2009 \\
\hline Local population density & 0 & & $\downarrow$ & $1994-2008$ \\
\hline Effectiveness & 0 & & & \\
\hline
\end{tabular}

Table 3. Results for Sureste Regional Park 


\begin{tabular}{|c|c|c|c|c|c|}
\hline \multicolumn{6}{|c|}{ Curso Medio del Río Guadarrama y su entorno Regional Park } \\
\hline \multicolumn{6}{|c|}{ Area (ha.): 22116} \\
\hline Designation date: 1999 & & & & ssessment date & 2009-10 \\
\hline Assessment number: 1 & & Perioc & city of asses & ssment: Every f & ive years \\
\hline Index / Indicator & Valuation & State & Tendency & $\begin{array}{c}\text { Measurement } \\
\text { period }\end{array}$ & Remarks \\
\hline State of Conservation & 0 & (8) & & & \\
\hline $\begin{array}{l}\text { Evolution of populations of } \\
\text { endangered species or } \\
\text { subspecies }\end{array}$ & 0 & (8) & NA & 1992-2008 & \\
\hline Health of vegetation & 1 & (9) & $\uparrow$ & $2002-2009$ & \\
\hline Surface water quality & 0 & (8) & NA & 2008 & \\
\hline Air quality & 0 & (8) & NA & 2008 & \\
\hline Presence of solid waste & 1 & (9) & NA & 2009 & \\
\hline Landscape impact & 1 & (9) & NA & 2009 & \\
\hline Planning & 0 & (8) & & & \\
\hline $\begin{array}{l}\text { Appropriateness of protection } \\
\text { legislation }\end{array}$ & 2 & (ن) & $\uparrow$ & 1992-2009 & \begin{tabular}{|l|} 
It was \\
declared \\
Preventive \\
Protection \\
Regime \\
from 1992 \\
till 1999 \\
\end{tabular} \\
\hline $\begin{array}{l}\text { Existence of updated planning } \\
\text { documents }\end{array}$ & 1 & $(-)$ & $\leftrightarrow$ & 1999-2009 & \\
\hline $\begin{array}{l}\text { Existence of updated documents } \\
\text { on social and economic } \\
\text { development }\end{array}$ & 0 & (8) & $\leftrightarrow$ & 1999-2009 & \\
\hline $\begin{array}{l}\text { Existence of updated } \\
\text { management documents }\end{array}$ & 0 & (8) & $\leftrightarrow$ & 1999-2009 & \\
\hline $\begin{array}{l}\text { Existence of updated documents } \\
\text { on public use }\end{array}$ & 1 & (-) & $\leftrightarrow$ & 1999-2009 & \\
\hline Zoning & 1 & (:) & $\leftrightarrow$ & 1999-2009 & \\
\hline $\begin{array}{l}\text { Evolution of the area designated } \\
\text { as protected }\end{array}$ & 2 & (:) & $\uparrow$ & $1999-2009$ & \\
\hline Management & 1 & (-) & & & \\
\hline $\begin{array}{l}\text { Degree of characterization of the } \\
\text { protected area }\end{array}$ & 0 & (2) & $\uparrow$ & 1999-2009 & \\
\hline $\begin{array}{l}\text { Degree of fulfillment of } \\
\text { management objectives }\end{array}$ & 1 & $(-)$ & NA & 2008 & \\
\hline $\begin{array}{l}\text { Evolution of feature(s) for which } \\
\text { the protected area was } \\
\text { designated }\end{array}$ & ¿? & & & & \\
\hline $\begin{array}{l}\text { Existence of sufficient } \\
\text { management staff }\end{array}$ & 2 & (:) & NA & 2005 & \\
\hline $\begin{array}{l}\text { Evolution of investment in the } \\
\text { protected area }\end{array}$ & 2 & (:) & $\downarrow$ & $2002-2009$ & \\
\hline $\begin{array}{l}\text { Effectiveness of public } \\
\text { participation bodies }\end{array}$ & 0 & (2) & $\leftrightarrow$ & 1999-2009 & \\
\hline $\begin{array}{l}\text { Production and distribution of an } \\
\text { annual report on activities and } \\
\text { outcomes }\end{array}$ & 2 & (:) & $\leftrightarrow$ & 1999-2009 & \\
\hline
\end{tabular}




\begin{tabular}{|c|c|c|c|c|c|}
\hline $\begin{array}{l}\text { Easiness to identify the protected } \\
\text { area }\end{array}$ & 2 & (ن) & NA & 2009 & \\
\hline Public use infrastructure & 1 & (9) & NA & 2009 & \\
\hline $\begin{array}{l}\text { Existence of environmental } \\
\text { education and volunteering } \\
\text { activities }\end{array}$ & 0 & & $\leftrightarrow$ & 1999-2009 & \\
\hline Sanctioning procedures & & & ¿? & & \\
\hline Monitoring activities & 1 & & & 1999-2009 & \\
\hline Social and Economic Context & 0 & (8) & & & \\
\hline $\begin{array}{l}\text { Number of municipalities in the } \\
\text { protected area }\end{array}$ & 0 & & NA & 2009 & \\
\hline $\begin{array}{l}\text { Area provided for the protected } \\
\text { area by municipalities under local } \\
\text { Agenda } 21\end{array}$ & 0 & & & 1999-2009 & \\
\hline Land ownership & 0 & & NA & 2005 & \\
\hline $\begin{array}{l}\text { Main economic activities in the } \\
\text { protected area }\end{array}$ & $i ?$ & & & & \\
\hline Land use changes & 1 & (9) & $\uparrow$ & $1990 ; 2000$ & \\
\hline $\begin{array}{l}\text { Social Perception and } \\
\text { Valuationl }\end{array}$ & 0 & & & & \\
\hline $\begin{array}{l}\text { Degree of knowledge on the } \\
\text { protected area }\end{array}$ & 1 & & $\uparrow$ & $2007 ; 2009$ & \\
\hline $\begin{array}{l}\text { Perception of the conservation } \\
\text { state }\end{array}$ & 0 & & $\uparrow$ & $2007 ; 2009$ & \\
\hline Personal importance & 2 & & $\uparrow$ & $2007 ; 2009$ & \\
\hline $\begin{array}{l}\text { Economic valuation of the } \\
\text { protected area }\end{array}$ & 1 & & $\downarrow$ & $2007 ; 2009$ & \\
\hline Threats to Conservation & 2 & & & & \\
\hline $\begin{array}{l}\text { Presence of alien invasive } \\
\text { species }\end{array}$ & 2 & & NA & 2009 & \\
\hline Climate change & 1 & (9) & NA & $1972-2003$ & \\
\hline Area affected by fires & 0 & & 个 & $2000-2008$ & \\
\hline Fragmentation & 1 & (9) & NA & 2000 & \\
\hline Isolation & 1 & (10) & $\downarrow$ & $1990 ; 2000$ & \\
\hline Accessibility & 2 & & NA & 2009 & \\
\hline Number of visitors & $i ?$ & & & & \\
\hline Activities performed by visitors & 0 & & NA & 2009 & \\
\hline Local population density & 1 & & $\downarrow$ & $2000-2008$ & \\
\hline Effectiveness & 0 & & & & \\
\hline
\end{tabular}

Table 4. Results for Curso Medio del Río Guadarrama y su entorno Regional Park 


\section{Pinar de Abantos y Zona de la Herrería Picturesque Landscape}

\section{Area (ha.): 1538,6}

\begin{tabular}{|c|c|c|c|c|c|}
\hline \multirow{2}{*}{\multicolumn{2}{|c|}{\begin{tabular}{|l|} 
Designation date: 1961 \\
Assessment number: 1
\end{tabular}}} & \multicolumn{4}{|c|}{ Assessment date: $2009-10$} \\
\hline & & & odicity of a & sessment: Eve & five years \\
\hline Index / Indicator & Valuation & State & Tendency & $\begin{array}{c}\text { Measurement } \\
\text { period }\end{array}$ & Remarks \\
\hline State of Conservation & 0 & (8) & & & \\
\hline $\begin{array}{l}\text { Evolution of populations of } \\
\text { endangered species or } \\
\text { subspecies }\end{array}$ & 0 & (8) & NA & 1961-2009 & \\
\hline Health of vegetation & 1 & $(-)$ & $\downarrow$ & $2002-2009$ & \\
\hline Surface water quality & ¿? & & & & \\
\hline Air quality & 1 & (9) & NA & 2008 & \\
\hline Presence of solid waste & 1 & (9) & NA & 2009 & \\
\hline Landscape impact & 1 & $(9)$ & NA & 2009 & \\
\hline Planning & 0 & (8) & & & \\
\hline $\begin{array}{l}\text { Appropriateness of protection } \\
\text { legislation }\end{array}$ & 0 & (8) & $\leftrightarrow$ & $1961-2010$ & \\
\hline $\begin{array}{l}\text { Existence of updated planning } \\
\text { documents }\end{array}$ & 2 & (:) & $\uparrow$ & $1961-2010$ & \\
\hline $\begin{array}{l}\text { Existence of updated } \\
\text { documents on social and } \\
\text { economic development }\end{array}$ & 0 & (8) & $\leftrightarrow$ & $1961-2010$ & \\
\hline $\begin{array}{l}\text { Existence of updated } \\
\text { management documents }\end{array}$ & 2 & (:) & $\uparrow$ & $1961-2010$ & \\
\hline $\begin{array}{l}\text { Existence of updated } \\
\text { documents on public use }\end{array}$ & 0 & (2) & $\leftrightarrow$ & $1961-2010$ & \\
\hline Zoning & 0 & (8) & $\leftrightarrow$ & $1961-2010$ & \\
\hline $\begin{array}{l}\text { Evolution of the area } \\
\text { designated as protected }\end{array}$ & 1 & (9) & $\leftrightarrow$ & $1961-2010$ & \\
\hline Management & 0 & (2) & & & \\
\hline $\begin{array}{l}\text { Degree of characterization of } \\
\text { the protected area }\end{array}$ & 1 & $(9)$ & $\uparrow$ & $1961-2009$ & \\
\hline $\begin{array}{l}\text { Degree of fulfillment of } \\
\text { management objectives }\end{array}$ & ¿? & & & & \\
\hline $\begin{array}{l}\text { Evolution of feature(s) for which } \\
\text { the protected area was } \\
\text { designated }\end{array}$ & ¿? & & & & \\
\hline $\begin{array}{l}\text { Existence of sufficient } \\
\text { management staff }\end{array}$ & 1 & (9) & NA & 2009 & \\
\hline $\begin{array}{l}\text { Evolution of investment in the } \\
\text { protected area }\end{array}$ & 1 & (1) & $\uparrow$ & 2009 & \\
\hline $\begin{array}{l}\text { Effectiveness of public } \\
\text { participation bodies }\end{array}$ & 0 & & $\leftrightarrow$ & $1961-2009$ & \\
\hline $\begin{array}{l}\text { Production and distribution of } \\
\text { an annual report on activities } \\
\text { and outcomes }\end{array}$ & 0 & (8) & $\leftrightarrow$ & $1961-2009$ & \\
\hline $\begin{array}{l}\text { Easiness to identify the } \\
\text { protected area }\end{array}$ & 0 & (2) & NA & 2009 & \\
\hline Public use infrastructure & 1 & $(\bullet)$ & NA & 2009 & \\
\hline
\end{tabular}




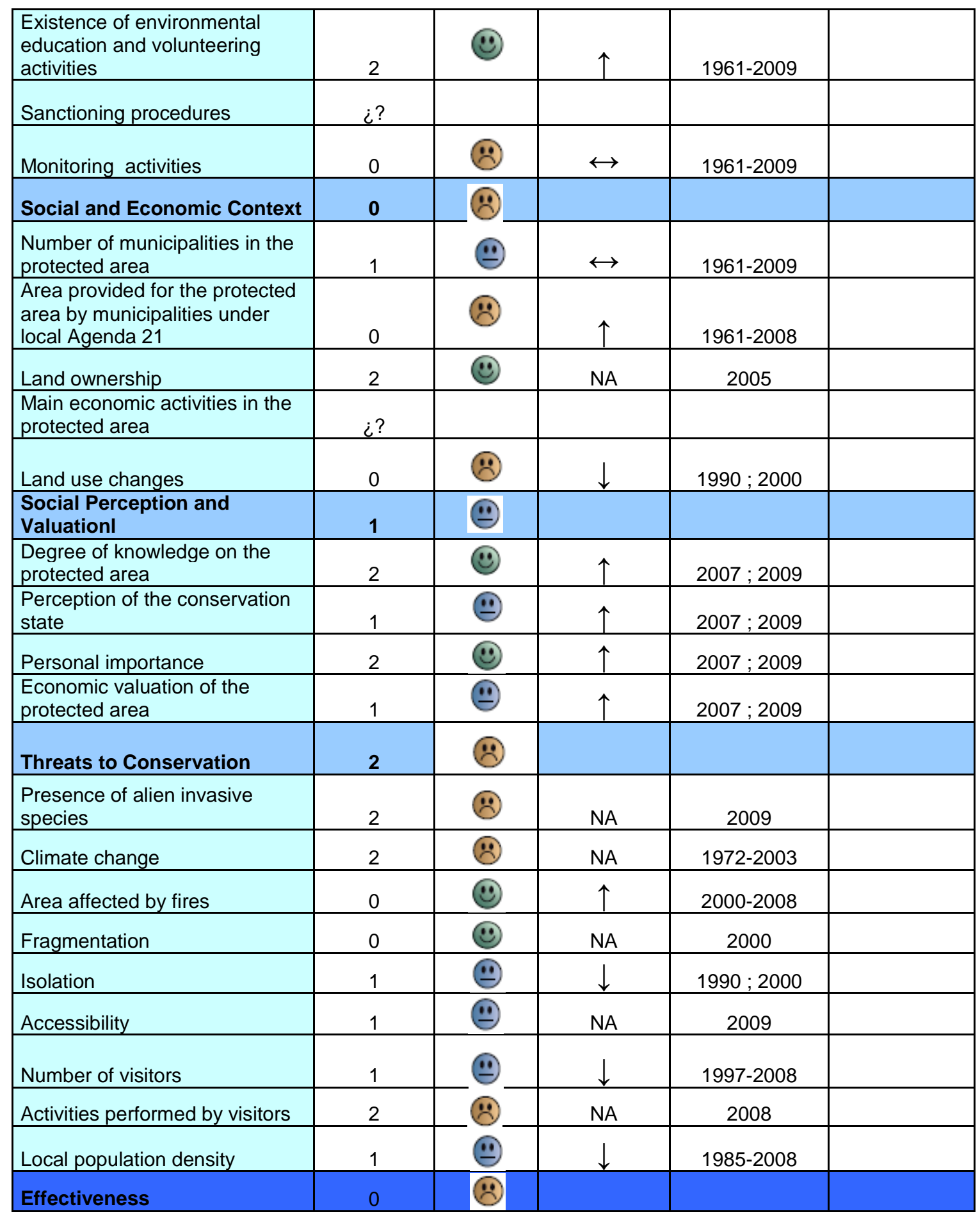

Table 5. Results for Pinar de Abantos y Zona de la Herrería Picturesque Landscape 
Natural Site of National Interest of Hayedo de Montejo de la Sierra

Area (ha.): 250

\begin{tabular}{|c|c|c|c|c|c|}
\hline \multicolumn{4}{|l|}{ Designation date: 1974} & \multicolumn{2}{|c|}{ Assessment date: $2009-10$} \\
\hline Assessment number: 1 & & & dicity of as & sessment: Eve & five years \\
\hline Index / Indicator & Valuation & State & Tendency & \begin{tabular}{|c|}
$\begin{array}{c}\text { Measurement } \\
\text { period }\end{array}$ \\
\end{tabular} & Remarks \\
\hline State of Conservation & 1 & (9) & & & \\
\hline $\begin{array}{l}\text { Evolution of populations of } \\
\text { endangered species or } \\
\text { subspecies }\end{array}$ & 0 & (8) & NA & 1974-2009 & \\
\hline Health of vegetation & ¿? & & & & \\
\hline Surface water quality & ¿? & & & & \\
\hline Air quality & 1 & (9) & NA & 2008 & \\
\hline Presence of solid waste & 2 & (:) & NA & 2009 & \\
\hline Landscape impact & 2 & (:) & NA & 2009 & \\
\hline Planning & 0 & (8) & & & \\
\hline $\begin{array}{l}\text { Appropriateness of protection } \\
\text { legislation }\end{array}$ & 0 & (8) & $\leftrightarrow$ & 1974-2009 & \\
\hline $\begin{array}{l}\text { Existence of updated planning } \\
\text { documents }\end{array}$ & 0 & (8) & $\leftrightarrow$ & 1974-2009 & \\
\hline $\begin{array}{l}\text { Existence of updated } \\
\text { documents on social and } \\
\text { economic development }\end{array}$ & 1 & (9) & $\leftrightarrow$ & $1974-2009$ & \\
\hline $\begin{array}{l}\text { Existence of updated } \\
\text { management documents }\end{array}$ & 0 & (8) & $\leftrightarrow$ & $1974-2009$ & \\
\hline $\begin{array}{l}\text { Existence of updated } \\
\text { documents on public use }\end{array}$ & 2 & (:) & $\uparrow$ & 1974-2009 & \\
\hline Zoning & 0 & (8) & $\uparrow$ & 1974-2009 & $\begin{array}{c}\text { Proposal in } \\
1992\end{array}$ \\
\hline $\begin{array}{l}\text { Evolution of the area } \\
\text { designated as protected }\end{array}$ & 1 & $(9)$ & $\leftrightarrow$ & $1974-2009$ & \\
\hline Management & 1 & (-) & & & \\
\hline $\begin{array}{l}\text { Degree of characterization of } \\
\text { the protected area }\end{array}$ & 0 & (8) & $\uparrow$ & 1974-2009 & \\
\hline $\begin{array}{l}\text { Degree of fulfillment of } \\
\text { management objectives }\end{array}$ & ¿? & & & & \\
\hline $\begin{array}{l}\text { Evolution of feature(s) for which } \\
\text { the protected area was } \\
\text { designated }\end{array}$ & ¿? & & & & \\
\hline $\begin{array}{l}\text { Existence of sufficient } \\
\text { management staff }\end{array}$ & 2 & (:) & NA & 2009 & \\
\hline $\begin{array}{l}\text { Evolution of investment in the } \\
\text { protected area }\end{array}$ & 2 & (:) & $\leftrightarrow$ & $1996-2009$ & \\
\hline $\begin{array}{l}\text { Effectiveness of public } \\
\text { participation bodies }\end{array}$ & 0 & (8) & $\leftrightarrow$ & $1974-2009$ & \\
\hline $\begin{array}{l}\text { Production and distribution of } \\
\text { an annual report on activities } \\
\text { and outcomes }\end{array}$ & 0 & (8) & $\leftrightarrow$ & 1974-2009 & \\
\hline $\begin{array}{l}\text { Easiness to identify the } \\
\text { protected area }\end{array}$ & 1 & (2) & NA & 2009 & \\
\hline Public use infrastructure & 2 & & NA & 2009 & \\
\hline
\end{tabular}




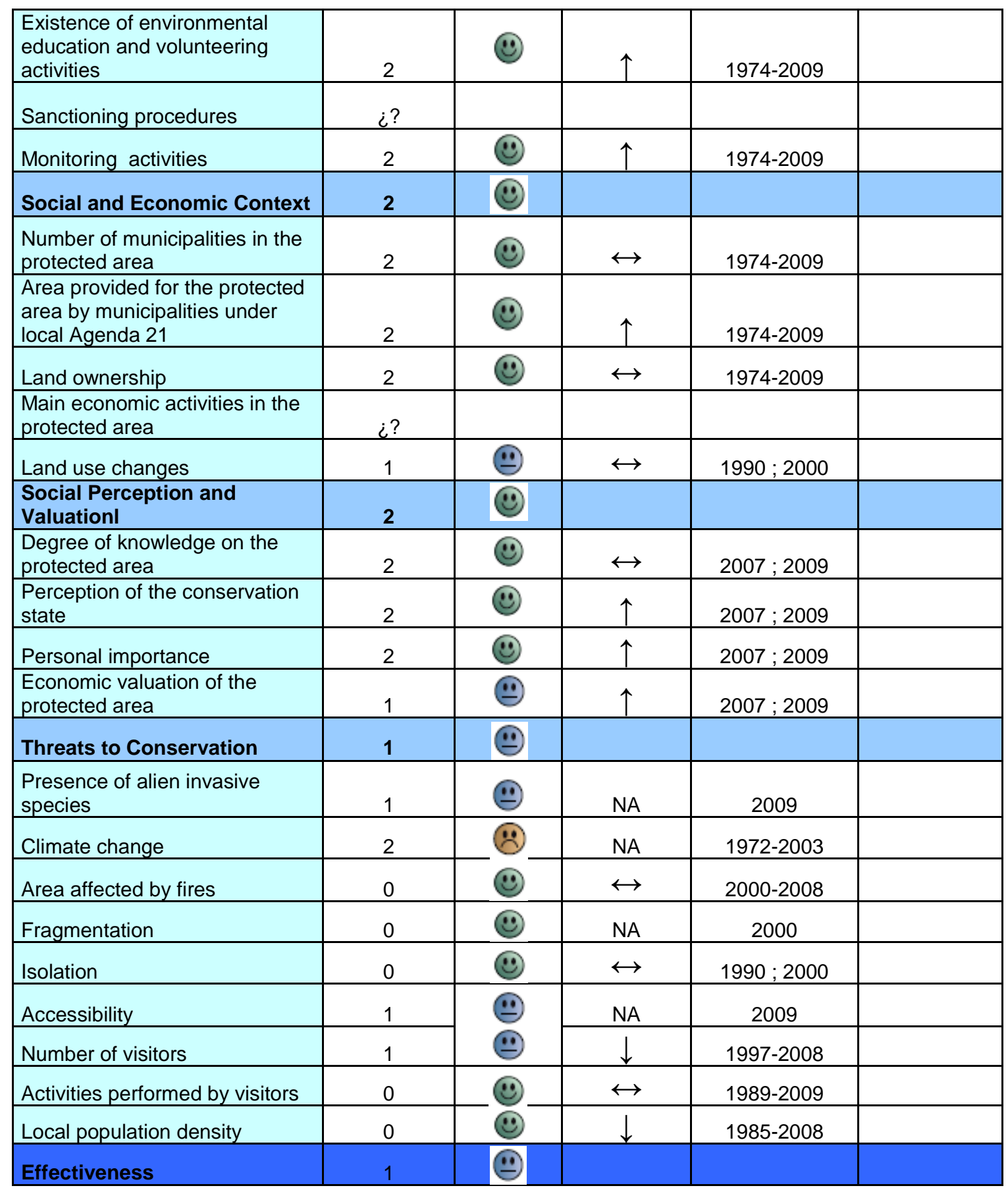

Table 6. Results for the Natural Site of National Interest of Hayedo de Montejo de la Sierra 
El Regajal-Mar de Ontígola Nature Reserve

\section{Area (ha.): 629,2}

\begin{tabular}{|c|c|c|c|c|c|}
\hline \multirow{2}{*}{\multicolumn{2}{|c|}{\begin{tabular}{|l|} 
Designation date: 1994 \\
Assessment number: 1
\end{tabular}}} & \multicolumn{4}{|c|}{ Assessment date: $2009-10$} \\
\hline & & & dicity of as & sessment: Eve & y five years \\
\hline Index / Indicator & Valuation & State & Tendency & \begin{tabular}{|c}
$\begin{array}{c}\text { Measurement } \\
\text { period }\end{array}$ \\
\end{tabular} & Remarks \\
\hline State of Conservation & 0 & (8) & & & \\
\hline $\begin{array}{l}\text { Evolution of populations of } \\
\text { endangered species or } \\
\text { subspecies }\end{array}$ & 0 & (8) & NA & & No data \\
\hline Health of vegetation & ¿? & & & & \\
\hline Surface water quality & 2 & (:) & NA & 1991 & $\begin{array}{c}\text { Weighted } \\
\text { valuation for } \\
6 \text { variables } \\
\text { measured } \\
\end{array}$ \\
\hline Air quality & 1 & $(-)$ & NA & 2008 & \\
\hline Presence of solid waste & 0 & (8) & NA & 2009 & \\
\hline Landscape impact & 0 & (8) & NA & 2009 & \\
\hline Planning & 2 & (:) & & & \\
\hline $\begin{array}{l}\text { Appropriateness of protection } \\
\text { legislation }\end{array}$ & 2 & (:) & $\leftrightarrow$ & 1994-2009 & \\
\hline $\begin{array}{l}\text { Existence of updated planning } \\
\text { documents }\end{array}$ & 2 & (:) & $\leftrightarrow$ & 1994-2009 & \\
\hline $\begin{array}{l}\text { Existence of updated } \\
\text { documents on social and } \\
\text { economic development }\end{array}$ & 0 & (8) & NA & 1994-2009 & \\
\hline $\begin{array}{l}\text { Existence of updated } \\
\text { management documents }\end{array}$ & 2 & (:) & $\leftrightarrow$ & 1994-2009 & $\begin{array}{l}\text { Natural } \\
\text { Resources } \\
\text { Plan } \\
\end{array}$ \\
\hline $\begin{array}{l}\text { Existence of updated } \\
\text { documents on public use }\end{array}$ & 1 & $(9)$ & $\uparrow$ & 1994-2009 & \\
\hline Zoning & 1 & $(-)$ & $\uparrow$ & 1994-2009 & \\
\hline $\begin{array}{l}\text { Evolution of the area } \\
\text { designated as protected }\end{array}$ & 2 & (:) & $\uparrow$ & 1994-2009 & \\
\hline Management & 0 & (8) & & & \\
\hline $\begin{array}{l}\text { Degree of characterization of } \\
\text { the protected area }\end{array}$ & 1 & (-) & $\uparrow$ & 1994-2009 & \\
\hline $\begin{array}{l}\text { Degree of fulfillment of } \\
\text { management objectives }\end{array}$ & 2 & (:) & NA & 2008 & \\
\hline $\begin{array}{l}\text { Evolution of feature(s) for which } \\
\text { the protected area was } \\
\text { designated }\end{array}$ & ¿? & & & & \\
\hline $\begin{array}{l}\text { Existence of sufficient } \\
\text { management staff }\end{array}$ & 0 & (8) & NA & 2009 & \\
\hline $\begin{array}{l}\text { Evolution of investment in the } \\
\text { protected area }\end{array}$ & 0 & (8) & $\downarrow$ & $2007-2009$ & \\
\hline $\begin{array}{l}\text { Effectiveness of public } \\
\text { participation bodies }\end{array}$ & 0 & (8) & $\leftrightarrow$ & 1994-2009 & \\
\hline $\begin{array}{l}\text { Production and distribution of } \\
\text { an annual report on activities } \\
\text { and outcomes }\end{array}$ & 0 & $(1$ & $\downarrow$ & 1994-2009 & \\
\hline $\begin{array}{l}\text { Easiness to identify the } \\
\text { protected area }\end{array}$ & 0 & 8 & NA & 2009 & \\
\hline
\end{tabular}




\begin{tabular}{|c|c|c|c|c|c|}
\hline Public use infrastructure & 0 & (В) & NA & 2009 & \\
\hline $\begin{array}{l}\text { Existence of environmental } \\
\text { education and volunteering } \\
\text { activities }\end{array}$ & 1 & & & 1994-2009 & \\
\hline Sanctioning procedures & ¿? & & & & \\
\hline Monitoring activities & 1 & & $\uparrow$ & 1994-2009 & \\
\hline Social and Economic Context & 0 & & & & \\
\hline $\begin{array}{l}\text { Number of municipalities in the } \\
\text { protected area }\end{array}$ & 2 & & $\leftrightarrow$ & 1994-2009 & \\
\hline $\begin{array}{l}\text { Area provided for the protected } \\
\text { area by municipalities under } \\
\text { local Agenda } 21\end{array}$ & 2 & & & 1994-2008 & \\
\hline Land ownership & 0 & & NA & 2005 & \\
\hline $\begin{array}{l}\text { Main economic activities in the } \\
\text { protected area }\end{array}$ & ¿? & & & & \\
\hline Land use changes & 0 & & $\downarrow$ & $1990 ; 2000$ & \\
\hline $\begin{array}{l}\text { Social Perception and } \\
\text { Valuationl }\end{array}$ & 1 & & & & \\
\hline $\begin{array}{l}\text { Degree of knowledge on the } \\
\text { protected area }\end{array}$ & 2 & & $\uparrow$ & $2007 ; 2009$ & \\
\hline $\begin{array}{l}\text { Perception of the conservation } \\
\text { state }\end{array}$ & 0 & & $\downarrow$ & $2007 ; 2009$ & \\
\hline Personal importance & 2 & & $\downarrow$ & $2007 ; 2009$ & \\
\hline $\begin{array}{l}\text { Economic valuation of the } \\
\text { protected area }\end{array}$ & 1 & & D & $2007 ; 2009$ & \\
\hline Threats to Conservation & 2 & & & & \\
\hline $\begin{array}{l}\text { Presence of alien invasive } \\
\text { species }\end{array}$ & 2 & & NA & 2009 & \\
\hline Climate change & 2 & & NA & $1972-2003$ & \\
\hline Area affected by fires & 0 & & $\uparrow$ & $2000-2008$ & \\
\hline Fragmentation & 1 & (9) & NA & 2000 & \\
\hline Isolation & 1 & (10) & $\downarrow$ & $1990 ; 2000$ & \\
\hline Accessibility & 2 & 2 & NA & 2009 & \\
\hline Number of visitors & $?$ & & & & \\
\hline Activities performed by visitors & 0 & () & NA & 2008 & \\
\hline Local population density & 1 & & $\downarrow$ & 1994-2008 & \\
\hline Effectiveness & 0 & (2) & & & \\
\hline
\end{tabular}

Table 7. Results for El Regajal-Mar de Ontígola Nature Reserve 


\section{Laguna de San Juan Fauna Refuge}

\section{Area (ha.): 47}

\begin{tabular}{|c|c|c|c|c|c|}
\hline \multirow{2}{*}{\multicolumn{2}{|c|}{$\begin{array}{l}\text { Designation date: } 1991 \\
\text { Assessment number: } 1\end{array}$}} & & & \multicolumn{2}{|c|}{ Assessment date: $2009-10$} \\
\hline & & \multicolumn{4}{|c|}{ Periodicity of assessment: Every five years } \\
\hline Index / Indicator & Valuation & State & Tendency & $\begin{array}{c}\text { Measurement } \\
\text { period }\end{array}$ & Remarks \\
\hline State of Conservation & 0 & (8) & & & \\
\hline $\begin{array}{l}\text { Evolution of populations of } \\
\text { endangered species or } \\
\text { subspecies }\end{array}$ & 0 & (8) & NA & & Sin datos \\
\hline Health of vegetation & ¿? & & & & \\
\hline Surface water quality & 0 & (8) & NA & 2007 & $\begin{array}{c}\text { Weighted } \\
\text { valuation for } 7 \\
\text { variables } \\
\text { measured }\end{array}$ \\
\hline Air quality & 0 & (8) & NA & 2008 & \\
\hline Presence of solid waste & 2 & (:) & NA & 2009 & \\
\hline Landscape impact & 1 & (9) & NA & 2009 & \\
\hline Planning & 0 & (2) & & & \\
\hline $\begin{array}{l}\text { Appropriateness of protection } \\
\text { legislation }\end{array}$ & 1 & $(-)$ & $\leftrightarrow$ & 1991-2009 & \\
\hline $\begin{array}{l}\text { Existence of updated planning } \\
\text { documents }\end{array}$ & 0 & (8) & $\leftrightarrow$ & $1991-2009$ & \\
\hline $\begin{array}{l}\text { Existence of updated } \\
\text { documents on social and } \\
\text { economic development }\end{array}$ & 0 & (8) & $\leftrightarrow$ & $1991-2009$ & \\
\hline $\begin{array}{l}\text { Existence of updated } \\
\text { management documents }\end{array}$ & 1 & (-) & $\uparrow$ & $1991-2009$ & \\
\hline $\begin{array}{l}\text { Existence of updated } \\
\text { documents on public use }\end{array}$ & 1 & $(9)$ & $\uparrow$ & $1991-2009$ & \\
\hline Zoning & 1 & $(-)$ & $\uparrow$ & 1991-2009 & \\
\hline $\begin{array}{l}\text { Evolution of the area } \\
\text { designated as protected }\end{array}$ & 1 & $(-)$ & $\leftrightarrow$ & $1991-2009$ & \\
\hline Management & 0 & (8) & & & \\
\hline $\begin{array}{l}\text { Degree of characterization of } \\
\text { the protected area }\end{array}$ & 1 & $(-)$ & $\uparrow$ & $1991-2009$ & \\
\hline $\begin{array}{l}\text { Degree of fulfillment of } \\
\text { management objectives }\end{array}$ & 0 & (8) & NA & 2008 & \\
\hline $\begin{array}{l}\text { Evolution of feature }(\mathrm{s}) \text { for which } \\
\text { the protected area was } \\
\text { designated }\end{array}$ & ¿? & & & & \\
\hline $\begin{array}{l}\text { Existence of sufficient } \\
\text { management staff }\end{array}$ & 0 & (8) & NA & 2009 & \\
\hline $\begin{array}{l}\text { Evolution of investment in the } \\
\text { protected area }\end{array}$ & 2 & (:) & $\uparrow$ & $2007-2009$ & \\
\hline $\begin{array}{l}\text { Effectiveness of public } \\
\text { participation bodies }\end{array}$ & 0 & (8) & $\leftrightarrow$ & 1991-2009 & \\
\hline $\begin{array}{l}\text { Production and distribution of } \\
\text { an annual report on activities } \\
\text { and outcomes }\end{array}$ & 0 & $\mathscr{6}$ & $\leftrightarrow$ & $1991-2009$ & \\
\hline $\begin{array}{l}\text { Easiness to identify the } \\
\text { protected area }\end{array}$ & 1 & $(9)$ & NA & 2009 & \\
\hline
\end{tabular}




\begin{tabular}{|c|c|c|c|c|c|}
\hline Public use infrastructure & 2 & (4) & NA & 2009 & \\
\hline $\begin{array}{l}\text { Existence of environmental } \\
\text { education and volunteering } \\
\text { activities }\end{array}$ & 0 & (2) & $\leftrightarrow$ & 1991-2009 & \\
\hline Sanctioning procedures & ¿? & & & & \\
\hline Monitoring activities & 1 & $(9)$ & $\uparrow$ & 1991-2009 & \\
\hline Social and Economic Context & 1 & (2) & & & \\
\hline $\begin{array}{l}\text { Number of municipalities in the } \\
\text { protected area }\end{array}$ & 2 & (4) & $\leftrightarrow$ & 1991-2009 & \\
\hline $\begin{array}{l}\text { Area provided for the protected } \\
\text { area by municipalities under } \\
\text { local Agenda } 21\end{array}$ & 0 & (8) & $\leftrightarrow$ & $1991-2008$ & \\
\hline Land ownership & 1 & (9) & NA & 2005 & \\
\hline $\begin{array}{l}\text { Main economic activities in the } \\
\text { protected area }\end{array}$ & ¿? & & & & \\
\hline Land use changes & 1 & (9) & $\leftrightarrow$ & $1990 ; 2000$ & \\
\hline $\begin{array}{l}\text { Social Perception and } \\
\text { Valuationl }\end{array}$ & 1 & (19) & & & \\
\hline $\begin{array}{l}\text { Degree of knowledge on the } \\
\text { protected area }\end{array}$ & 2 & (i) & $\uparrow$ & $2007 ; 2009$ & \\
\hline $\begin{array}{l}\text { Perception of the conservation } \\
\text { state }\end{array}$ & 0 & $(8)$ & $\uparrow$ & $2007 ; 2009$ & \\
\hline Personal importance & 2 & (4) & $\downarrow$ & $2007 ; 2009$ & \\
\hline $\begin{array}{l}\text { Economic valuation of the } \\
\text { protected area }\end{array}$ & 1 & (9) & $\downarrow$ & $2007 ; 2009$ & \\
\hline Threats to Conservation & 0 & (ن) & & & \\
\hline $\begin{array}{l}\text { Presence of alien invasive } \\
\text { species }\end{array}$ & 2 & (8) & NA & 2009 & \\
\hline Climate change & 2 & (8) & NA & $1972-2003$ & \\
\hline Area affected by fires & 0 & (:) & $\uparrow$ & 2000-2008 & \\
\hline Fragmentation & 0 & (:) & NA & 2000 & \\
\hline Isolation & 0 & (:) & $\leftrightarrow$ & $1990 ; 2000$ & \\
\hline Accessibility & 0 & (1) & NA & 2009 & \\
\hline Number of visitors & ¿? & & & & \\
\hline Activities performed by visitors & 0 & (:) & NA & 2008 & \\
\hline Local population density & 0 & (9) & $\leftrightarrow$ & $1991-2008$ & \\
\hline Effectiveness & 0 & 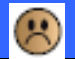 & & & \\
\hline
\end{tabular}

Table 8. Results for Laguna de San Juan Fauna Refuge 
Natural Monument of National Interest of Peña del Arcipreste de Hita

\section{Area (ha.): 2,65}

\begin{tabular}{|c|c|c|c|c|c|}
\hline Designation date: 1930 & & & & Assessment d & te: $2009-10$ \\
\hline Assessment number: 1 & & & odicity of as & sessment: Eve & y five years \\
\hline Index / Indicator & Valuation & State & Tendency & $\begin{array}{c}\text { Measurement } \\
\text { period }\end{array}$ & Remarks \\
\hline State of Conservation & 0 & (8) & & & \\
\hline $\begin{array}{l}\text { Evolution of populations of } \\
\text { endangered species or } \\
\text { subspecies }\end{array}$ & 0 & (8) & NA & & No data \\
\hline Health of vegetation & ¿? & & & & \\
\hline Surface water quality & ¿? & & & & \\
\hline Air quality & 2 & (:) & NA & 2008 & \\
\hline Presence of solid waste & 2 & (:) & NA & 2009 & \\
\hline Landscape impact & 0 & (8) & NA & 2009 & \\
\hline Planning & 0 & (8) & & & \\
\hline $\begin{array}{l}\text { Appropriateness of protection } \\
\text { legislation }\end{array}$ & 0 & (8) & $\leftrightarrow$ & $1930-2009$ & \\
\hline $\begin{array}{l}\text { Existence of updated planning } \\
\text { documents }\end{array}$ & 0 & (8) & $\leftrightarrow$ & $1930-2009$ & \\
\hline $\begin{array}{l}\text { Existence of updated } \\
\text { documents on social and } \\
\text { economic development }\end{array}$ & 0 & (8) & $\leftrightarrow$ & $1930-2009$ & \\
\hline $\begin{array}{l}\text { Existence of updated } \\
\text { management documents }\end{array}$ & 0 & (8) & $\leftrightarrow$ & $1930-2009$ & \\
\hline $\begin{array}{l}\text { Existence of updated } \\
\text { documents on public use }\end{array}$ & 0 & (8) & $\leftrightarrow$ & $1930-2009$ & \\
\hline Zoning & 0 & (8) & $\leftrightarrow$ & $1930-2009$ & \\
\hline $\begin{array}{l}\text { Evolution of the area } \\
\text { designated as protected }\end{array}$ & 1 & (9) & $\leftrightarrow$ & 1930-2009 & \\
\hline Management & 0 & (8) & & & \\
\hline $\begin{array}{l}\text { Degree of characterization of } \\
\text { the protected area }\end{array}$ & 0 & (8) & $\uparrow$ & $1930-2009$ & \\
\hline $\begin{array}{l}\text { Degree of fulfillment of } \\
\text { management objectives }\end{array}$ & ¿? & & & & \\
\hline $\begin{array}{l}\text { Evolution of feature }(\mathrm{s}) \text { for which } \\
\text { the protected area was } \\
\text { designated }\end{array}$ & ¿? & & & & \\
\hline $\begin{array}{l}\text { Existence of sufficient } \\
\text { management staff }\end{array}$ & 0 & (8) & NA & 2009 & \\
\hline $\begin{array}{l}\text { Evolution of investment in the } \\
\text { protected area }\end{array}$ & ¿? & & & & \\
\hline $\begin{array}{l}\text { Effectiveness of public } \\
\text { participation bodies }\end{array}$ & 0 & (8) & $\leftrightarrow$ & 1930-2009 & \\
\hline $\begin{array}{l}\text { Production and distribution of } \\
\text { an annual report on activities } \\
\text { and outcomes }\end{array}$ & 0 & 6 & $\leftrightarrow$ & 1930-2009 & \\
\hline $\begin{array}{l}\text { Easiness to identify the } \\
\text { protected area }\end{array}$ & 0 & (8) & NA & 2009 & \\
\hline Public use infrastructure & 0 & () & NA & 2009 & \\
\hline
\end{tabular}




\begin{tabular}{|c|c|c|c|c|c|}
\hline $\begin{array}{l}\text { Existence of environmental } \\
\text { education and volunteering } \\
\text { activities }\end{array}$ & 0 & & $\leftrightarrow$ & 1930-2009 & \\
\hline Sanctioning procedures & ¿? & & & & \\
\hline Monitoring activities & 0 & & $\leftrightarrow$ & 1930-2009 & \\
\hline Social and Economic Context & 1 & 2) & & & \\
\hline $\begin{array}{l}\text { Number of municipalities in the } \\
\text { protected area }\end{array}$ & 2 & & $\leftrightarrow$ & 1930-2009 & \\
\hline $\begin{array}{l}\text { Area provided for the protected } \\
\text { area by municipalities under } \\
\text { local Agenda } 21\end{array}$ & 0 & & $\leftrightarrow$ & 1930-2008 & \\
\hline Land ownership & 2 & & NA & 2005 & \\
\hline $\begin{array}{l}\text { Main economic activities in the } \\
\text { protected area }\end{array}$ & ¿? & & & & \\
\hline Land use changes & 1 & & $\leftrightarrow$ & $1990 ; 2000$ & \\
\hline $\begin{array}{l}\text { Social Perception and } \\
\text { Valuationl }\end{array}$ & 1 & & & & \\
\hline $\begin{array}{l}\text { Degree of knowledge on the } \\
\text { protected area }\end{array}$ & 1 & & $\uparrow$ & $2007 ; 2009$ & \\
\hline $\begin{array}{l}\text { Perception of the conservation } \\
\text { state }\end{array}$ & 1 & & $\leftrightarrow$ & $2007 ; 2009$ & \\
\hline Personal importance & 1 & & $\downarrow$ & $2007 ; 2009$ & \\
\hline $\begin{array}{l}\text { Economic valuation of the } \\
\text { protected area }\end{array}$ & 2 & & $\downarrow$ & $2007 ; 2009$ & \\
\hline Threats to Conservation & 0 & ) & & & \\
\hline $\begin{array}{l}\text { Presence of alien invasive } \\
\text { species }\end{array}$ & 0 & & NA & 2009 & \\
\hline Climate change & 1 & (10) & NA & $1972-2003$ & \\
\hline Area affected by fires & 0 & & $\leftrightarrow$ & $2000-2008$ & \\
\hline Fragmentation & 0 & & $\mathrm{NA}$ & 2000 & \\
\hline Isolation & 0 & & $\leftrightarrow$ & $1990 ; 2000$ & \\
\hline Accessibility & 1 & (19) & NA & 2009 & \\
\hline Number of visitors & ¿? & & & & \\
\hline Activities performed by visitors & 0 & (0) & NA & 2009 & \\
\hline Local population density & 1 & (0) & $\downarrow$ & $1985-2008$ & \\
\hline Effectiveness & 0 & & & & \\
\hline
\end{tabular}

Table 9. Results for the Natural Monument of National Interest of Peña del Arcipreste de Hita 


\section{Preventive Protection Regime of Soto del Henares}

\section{Area (ha.): 332}

\begin{tabular}{|c|c|c|c|c|c|}
\hline \multicolumn{4}{|l|}{ Designation date: 2000} & \multicolumn{2}{|c|}{ Assessment date: $2009-10$} \\
\hline Assessment number: 1 & & \multicolumn{4}{|c|}{ Periodicity of assessment: Every five years } \\
\hline Index / Indicator & Valuation & State & Tendency & $\begin{array}{c}\text { Measurement } \\
\text { period }\end{array}$ & Remarks \\
\hline State of Conservation & 0 & (8) & & & \\
\hline $\begin{array}{l}\text { Evolution of populations of } \\
\text { endangered species or } \\
\text { subspecies }\end{array}$ & 0 & (8) & NA & & No data \\
\hline Health of vegetation & ¿? & & & & \\
\hline Surface water quality & 0 & (8) & $\downarrow$ & $2004 ; 2008$ & \\
\hline Air quality & 0 & (8) & NA & 2008 & \\
\hline Presence of solid waste & 0 & (8) & NA & 2009 & \\
\hline Landscape impact & 1 & $(9)$ & NA & 2009 & \\
\hline Planning & 0 & (8) & & & \\
\hline $\begin{array}{l}\text { Appropriateness of protection } \\
\text { legislation }\end{array}$ & 1 & (9) & $\leftrightarrow$ & $2000-2009$ & \\
\hline $\begin{array}{l}\text { Existence of updated planning } \\
\text { documents }\end{array}$ & 0 & (8) & $\leftrightarrow$ & $2000-2009$ & \\
\hline $\begin{array}{l}\text { Existence of updated } \\
\text { documents on social and } \\
\text { economic development }\end{array}$ & 0 & (8) & $\leftrightarrow$ & $2000-2009$ & \\
\hline $\begin{array}{l}\text { Existence of updated } \\
\text { management documents }\end{array}$ & 0 & (8) & $\leftrightarrow$ & $2000-2009$ & \\
\hline $\begin{array}{l}\text { Existence of updated } \\
\text { documents on public use }\end{array}$ & 0 & (8) & $\leftrightarrow$ & $2000-2009$ & \\
\hline Zoning & 0 & (8) & $\leftrightarrow$ & $2000-2009$ & \\
\hline $\begin{array}{l}\text { Evolution of the area } \\
\text { designated as protected }\end{array}$ & 1 & $(\bullet)$ & $\leftrightarrow$ & 2000-2009 & \\
\hline Management & 0 & (8) & & & \\
\hline $\begin{array}{l}\text { Degree of characterization of } \\
\text { the protected area }\end{array}$ & 1 & $(9)$ & $\uparrow$ & $2000-2009$ & \\
\hline $\begin{array}{l}\text { Degree of fulfillment of } \\
\text { management objectives }\end{array}$ & ¿? & & & & \\
\hline $\begin{array}{l}\text { Evolution of feature(s) for } \\
\text { which the protected area was } \\
\text { designated }\end{array}$ & ¿? & & & & \\
\hline $\begin{array}{l}\text { Existence of sufficient } \\
\text { management staff }\end{array}$ & 0 & (8) & NA & 2009 & \\
\hline $\begin{array}{l}\text { Evolution of investment in the } \\
\text { protected area }\end{array}$ & 1 & $(9)$ & $\downarrow$ & $2007-2009$ & \\
\hline $\begin{array}{l}\text { Effectiveness of public } \\
\text { participation bodies }\end{array}$ & 0 & (8) & $\leftrightarrow$ & $2000-2009$ & \\
\hline $\begin{array}{l}\text { Production and distribution of } \\
\text { an annual report on activities } \\
\text { and outcomes }\end{array}$ & 0 & (8) & $\leftrightarrow$ & $2000-2009$ & \\
\hline $\begin{array}{l}\text { Easiness to identify the } \\
\text { protected area }\end{array}$ & 0 & (8) & NA & 2009 & \\
\hline
\end{tabular}




\begin{tabular}{|c|c|c|c|c|c|}
\hline Public use infrastructure & 0 & $\mathscr{U}$ & NA & 2009 & \\
\hline $\begin{array}{l}\text { Existence of environmental } \\
\text { education and volunteering } \\
\text { activities }\end{array}$ & 0 & & $\leftrightarrow$ & 2000-2009 & \\
\hline Sanctioning procedures & ¿? & & & & \\
\hline Monitoring activities & 1 & & $\leftrightarrow$ & $2000-2009$ & \\
\hline $\begin{array}{l}\text { Social and Economic } \\
\text { Context }\end{array}$ & 1 & & & & \\
\hline $\begin{array}{l}\text { Number of municipalities in the } \\
\text { protected area }\end{array}$ & 1 & & $\leftrightarrow$ & 2000-2009 & \\
\hline $\begin{array}{l}\text { Area provided for the } \\
\text { protected area by } \\
\text { municipalities under local } \\
\text { Agenda } 21\end{array}$ & 0 & & $\uparrow$ & $2000-2008$ & \\
\hline Land ownership & 2 & & NA & 2005 & \\
\hline $\begin{array}{l}\text { Main economic activities in the } \\
\text { protected area }\end{array}$ & ¿? & & & & \\
\hline Land use changes & 1 & & $\uparrow$ & $1990 ; 2000$ & \\
\hline $\begin{array}{l}\text { Social Perception and } \\
\text { Valuationl }\end{array}$ & 1 & & & & \\
\hline $\begin{array}{l}\text { Degree of knowledge on the } \\
\text { protected area }\end{array}$ & 0 & & NA & 2009 & \\
\hline $\begin{array}{l}\text { Perception of the conservation } \\
\text { state }\end{array}$ & 0 & & NA & 2009 & \\
\hline Personal importance & 2 & & NA & 2009 & \\
\hline $\begin{array}{l}\text { Economic valuation of the } \\
\text { protected area }\end{array}$ & 2 & & NA & 2009 & \\
\hline Threats to Conservation & 1 & & & & \\
\hline $\begin{array}{l}\text { Presence of alien invasive } \\
\text { species }\end{array}$ & 0 & & NA & 2009 & \\
\hline Climate change & 1 & & NA & $1972-2003$ & \\
\hline Area affected by fires & 0 & & 个 & $2000-2008$ & \\
\hline Fragmentation & 0 & & NA & 2000 & \\
\hline Isolation & 0 & 9 & T & $1990 ; 2000$ & \\
\hline Accessibility & 1 & (10) & NA & 2009 & \\
\hline Number of visitors & ¿? & & & & \\
\hline Activities performed by visitors & 0 & & NA & 2009 & \\
\hline Local population density & 2 & & $\downarrow$ & $1985-2008$ & \\
\hline Effectiveness & 0 & & & & \\
\hline
\end{tabular}

Table 10. Results for the Preventive Protection Regime of Soto del Henares 